NBER WORKING PAPER SERIES

\title{
AFFILIATE ACTIVITY IN JAPANESE AND U.S. MULTINATIONALS AND JAPANESE EXPORTS, 1986-1995
}

\author{
Robert E. Lipsey \\ Eric D. Ramstetter \\ Working Paper 8581 \\ http://www.nber.org/papers/w8581
NATIONAL BUREAU OF ECONOMIC RESEARCH
1050 Massachusetts Avenue
Cambridge, MA 02138
November 2001

This paper is based on results in Lipsey, Ramstetter, and Blomström (2000a). The authors would like to thank members of the Committee for Analysis of the Survey of Overseas Business Activities of Japanese Companies (Nihon Kigyou no Kaigai Jigyou Katsudou Chousa Bunseki Kenkyukai), particularly Kyoji Fukao, for comments on related research and for information that helped the authors understand the nature of the data being used. Li Xu provided valuable research assistance. The views expressed herein are those of the authors and not necessarily those of the National Bureau of Economic Research.

(C) 2001 by Robert E. Lipsey and Eric D. Ramstetter. All rights reserved. Short sections of text, not to exceed two paragraphs, may be quoted without explicit permission provided that full credit, including $(\mathrm{C}$ notice, is given to the source. 
Affiliate Activity in Japanese and U.S. Multinationals and Japanese Exports, 1986-1995

Robert E. Lipsey and Eric D. Ramstetter

NBER Working Paper No. 8581

November 2001

JEL No. F23

\begin{abstract}
This study examines the relationship between Japan's manufactured exports to individual markets and the economic activities of foreign manufacturing affiliates of Japanese multinational corporations (MNCs) and U.S. MNCs in those markets. First, the relationships between Japanese export levels and employment in foreign affiliates of Japanese MNCs are analyzed in the context of a typical gravity model explaining the cross-country variation of Japan's manufacturing exports. Second, the paper examines the effects of the presence of affiliates of U.S. MNCs on Japanese export levels. And third, it analyzes the relation of changes in Japanese exports to levels of and changes in employment in Japanese and U.S. MNC affiliates.

The level of Japan's manufactured exports to a country is almost always positively related to employment in foreign manufacturing affiliates of Japanese MNCs there. There is no evidence that Japanese-owned host country production replaces Japanese exports. However, production by U.S. MNC affiliates in a country often tends to reduce Japanese exports to that market.

In some industries and periods, the initial level of Japanese affiliate employment, or changes in Japanese affiliate employment, are positively and significantly correlated with changes in Japan's exports, and there are no cases of significant negative relationships. The predominant effect of U.S. affiliates' presence on changes in Japanese exports to a country is negative, but the evidence for that effect is not strong.
\end{abstract}

Robert E. Lipsey

National Bureau of Economic Research

New York, NY, USA

rlipsey@gc.cuny.edu
Eric D. Ramstetter

International Research Centre for the Study of East Asian Development Kitakyushu, Japan ramst@icsead.or.jp 


\section{Introduction}

This purpose of this study is to examine the relationship between Japanese manufactured exports to individual markets and economic activity in foreign manufacturing affiliates of Japanese and U.S. multinational corporations (MNCs) in those markets. The relationship between home country exports and economic activities of foreign affiliates of home-based MNCs has long been a topic of interest to policy makers and academic economists alike. The most detailed studies of this relationship use firm-level data and have focused primarily on the United States and Sweden, because those are the countries that have published the most data on their firms' foreign operations and permitted the analysis of individual firm data. Recently, access to the firm-level data underlying surveys of Japan's MNCs by MITI (Ministry of International Trade and Industry, various years and 1998), has facilitated similarly detailed studies of the relationship between exports by Japanese MNC parents and economic activities in affiliates of those MNCs (e.g., Amano, Fukao, and Toyonaga 1998; Fukao and Chong 1997; Lipsey, Ramstetter, and Blomström 1999, 2000b). ${ }^{1}$ However, it is also of great interest from a public policy point of view to ask how production abroad is related to a home country's aggregate exports, rather than only the exports of parents. Such production might have an impact on the country's non-multinational firms different from that on the parent firms. For example, foreign production might favor exporting by parents at the expense of exporting by non-multinational Japanese firms. As pointed out in Lipsey, Ramstetter, and Blomström (1999, 2000b), there are as yet no studies for Japan that relate all

\footnotetext{
${ }^{1}$ Belderbos and Sleuwagen (1994) and Ramstetter (1997) are some other studies of firm-level data based on more limited samples from other sources.
} 
home country exports, including exports of non-MNCs, to the economic activities of foreign affiliates, as in studies of Sweden and the United States (e.g., Blomström, Lipsey, and Kulchycky 1988). This study tries to fill this gap in the literature by presenting evidence on this relationship for Japanese manufacturing industries in 1986, 1989, 1992, and 1995 and the periods bounded by these years.

To do this, section 2 first examines the relationship between the level of Japanese exports to a country and the level of Japanese affiliate employment there, in relatively large samples of 96-98 trading partners.

Section 3, for smaller samples of 41-48 trading partners, introduces the possibility that Japanese exports to a country are adversely affected by the activity of competing MNCs from the United States. That would seem likely if the activity of U.S. affiliates in a host country encouraged imports from the United States, as has been found in many studies. Section 4 then examines the effects of initial year employment or changes in employment of Japanese affiliates on changes in Japanese exports and Section 5 adds initial employment or changes in employment of U.S. manufacturing affiliates to this analysis. Finally, section 6 offers some concluding remarks.

2. Japan's Manufactured Exports and Employment in Japanese Manufacturing Affiliates

As in previous studies of this nature, a typical gravity model is taken as the basis for explaining the variation of Japan's manufacturing exports across countries. ${ }^{2}$ Explanatory country variables include its size,

\footnotetext{
${ }^{2}$ Manufactured exports and manufacturing affiliates are defined here to exclude oil and coal products, except for Japanese affiliates. In the case of Japanese affiliates, revised estimates of affiliate employment from the panel data underlying Fukao,
} 
measured by real gross domestic product (GDP), per capita GDP, and its distance from Japan. The sign of the coefficient on the GDP variable is expected to be positive, reflecting the positive influence of larger size on the demand for imports in a given country. Conversely, the sign of the coefficient on the distance variable is expected to be negative as the distance variable is thought to be positively correlated with transactions costs incurred in trade between Japan and a given country. As discussed in Blomström, Lipsey, and Kulchycky (1988), the sign of the coefficient on per capita GDP is indeterminate a priori. Generally, one would expect a positive coefficient when the income elasticity of demand is high and a negative coefficient when income elasticity is low. However, there are also supply-side effects that this variable could represent. For example, high per capita GDP could also be correlated with a strong comparative advantage in skill-intensive products and thus low import demand for these products. If this influence is dominant, coefficients could be negative even in the presence of high income elasticity of demand.

To this basic gravity model, a measure of employment in Japanese manufacturing affiliates in the partner country is added to see if there is any relationship between employment in Japanese affiliates and Japan's exports to that country, after the standard gravity effects have been accounted for. In this paper, we use revised estimates of affiliate employment from Fukao, Yuan, and Sakishita (1999) to measure affiliate activity. Estimates of affiliate employment and sales from this source are the most comprehensive and consistent

Yuan, and Sakishita (1999) include some oil and coal product manufacturing affiliates in chemicals and other manufacturing. However, these affiliates are relatively small in the Japanese case (see Lipsey, Ramstetter, and Blomström 2000a, Table 1).

A more troublesome aspect of the focus on manufacturing affiliates is the implicit assumption that the effects of trading affiliates are negligible, or at least that they do not obscure the effects of manufacturing affiliates. 
estimates of Japanese affiliate activity available. Affiliate employment should be more correlated with affiliate

production than affiliate sales, because sales might include resales of products from the parent firm. ${ }^{3}$

The resulting equation is:

(1a) $\mathrm{JXH}=$ fla(GDPH, GDPPH, DISTH, AERH)

where:

$\mathrm{JXH}=$ exports by Japan in industry $\mathrm{i}$ to country $\mathrm{h}$ (million yen, translated from US dollars at period average

exchange rates) ${ }^{4}$,

$\mathrm{GDPH}=$ real GDP in current international prices of country $\mathrm{h}$ (million yen, translated from international dollars

at PPP exchange rates),

GDPPH $=$ real GDP per capita in current international prices of country $\mathrm{h}$ (million yen, translated from

international dollars at PPP exchange rates) ${ }^{5}$,

${ }^{3}$ Affiliate value added is closer to the idea of affiliate production. However, as detailed elsewhere (e.g., Lipsey, Ramstetter, and Blomström (1999; 2000b), one of the biggest problems encountered when using MITI's MNC survey data (Ministry of International Trade and Industry, various years, 2000) is the fact that the coverage of the MITI surveys varies greatly from year to year and from variable to variable within single years. The revised estimates of affiliate employment and sales from Fukao, Yuan, and Sakishita (1999) include estimates for non-replying firms, resulting in much larger estimates of affiliate employment. For example, employment of affiliates reporting value added was only 47-89 percent of employment for all reporting affiliates and only 32-51 percent of revised employment estimates in 1986, 1989, 1992, and 1995 (Lipsey, Ramstetter, and Blomström (2000a, Table 1). The compilations of revised employment estimates used in this study differ slightly from the published results Fukao, Yuan, and Sakishita (1999) in some industries. The cause of these differences is unknown but these differences are very small.

${ }^{4}$ Japanese export data are calculated from Statistics Canada (1999), using the concordance given in Feenstra, Lipsey, and Bowen, 1997, pp. 45-60, modified to include chemical fibers in textiles, not chemicals.

${ }^{5}$ Per capita GDP data 1986-1992 are generally taken from Penn World Tables (1995) and 1995 figures are usually estimated by multiplying the 1992 figure from this source and growth rates (in current international dollars) for 1992-1995 from World Bank (1999). Some missing values are approximated by taking ratios to U.S. per capita GDP from World Bank (1999) or from adjacent years and multiplying them by U.S. estimates for the missing year. Total GDP is then 
$\mathrm{DISTH}=$ distance of country $\mathrm{h}$ from Japan ${ }^{6}$,

$\mathrm{AERH}=$ revised employment estimates for Japanese affiliates calculated from panel data compiled by Fukao,

Yuan, and Sakishita (1999) and provided by Ministry of International Trade and Industry (2000).

Although employment is closely correlated with production, there are differences between distributions

of value added across host countries and distributions of employment. In addition to differences in survey

coverage, these result from differences in average labor productivity across countries and differences in labor

intensity across industries. For example, North American and European economies tend to be larger in terms of

value added than in terms of employment because they are characterized by relatively high average labor

productivity. Chemical industries tend to be larger in terms of value added because they are relatively

capital-intensive. However, in various papers in which we have used both affiliate value added and affiliate

employment (Lipsey, Ramstetter, and Blomström 1999, 2000a, 2000b; Ramstetter 2001), the results were

qualitatively similar regardless of the measure used.

Equation (1a) is estimated in cross sections of Japan's trading partners for 1986, 1989, 1992, and 1995, and coefficients on affiliate employment, their significance levels, and the adjusted R-squared values from OLS

estimated as per capita GDP multiplied by total population taken from World Bank (1999). Data for Taiwan are approximated using real growth rates and exchange rates from International Centre for the Study of East Asian Development (2000). See Lipsey, Ramstetter, and Blomström (1999, Appendix Table B1) for further details.

${ }^{6}$ Distance data come from Edward W. Sweetman Co. (1965) and U.S. Navy Department (1943); see Lipsey, Ramstetter, and Blomström (1999, Appendix Table B1) for further details. 
estimation of equation (1a) are reported in Table $1{ }^{7}$ In general, gravity models performed in accordance with expectations, though coefficients were not always significant (see Appendix Table A1 for details). The explanatory power of many of the gravity equations was quite high for cross section analysis as evidenced by the relatively high values of the adjusted $\mathrm{R}$-squared.

The vast majority of the 36 coefficients on employment in Japanese affiliates are positive, and a large number of them are statistically significant at the 5 percent level or better (Table 1). Only in wood, furniture, and paper, an insignificant Japanese export industry, were there no significant coefficients on affiliate employment. All but one of the coefficients for the machinery industries are positive and significant. In these industries, which accounted for over three-fourths of Japan's manufactured exports, ${ }^{8}$ Japanese exports are larger to countries with a relatively large Japanese affiliate presence. The story is similar in chemicals, another relatively large export industry. In the other relatively large export industry, metals, the results are more mixed with fewer significant coefficients and negative, though insignificant, coefficients in 1986.

3. Japan's Manufactured Exports and Employment in U.S. Manufacturing Affiliates

\footnotetext{
${ }^{7}$ Detailed estimation results for this and other specifications using affiliate value added and alternate estimates of affiliate employment are reported in Lipsey, Ramstetter, and Blomström (2000a, Appendix Table A1). Here and in subsequent regressions, White's heteroscedasticity- consistent variance-covariance matrix is used to calculate standard errors when White's F-test for heteroscedasticity is significant at the 5 percent level or better (White 1980).

${ }^{8}$ Machinery categories combined to account for 77 percent of all non-oil manufacturing exports in 1986, 78 percent in 1989 , 79 percent in 1992, and 78 percent in 1995. Chemicals (5 percent of the total in 1986, 6 percent in 1989 and 1992, and 7 percent in 1995) and metals (9 percent in 1986, 8 percent in 1989, 6 percent in 1992, and 7 percent in 1995) were the other relatively large export industries (calculations from Statistics Canada 1999 using the concordance given in Feenstra, Lipsey, and Bowen 1997, pp. 45-60 modified to include chemical fibers in textiles, not chemicals).
} 
If the activities of Japanese affiliates are positively associated with Japanese exports, it is reasonable to expect that the activity of affiliates from other countries promotes those countries' exports to the host countries. Unless the additional exports come entirely from the enlargement of markets or the displacement of host country suppliers, some could be at the expense of Japanese exporters. To investigate this possibility, we add employment of majority-owned U.S. affiliates to equation (1a), as follows:

(2a) $\mathrm{JXH}=\mathrm{f} 2 \mathrm{~d}(\mathrm{GDPH}, \mathrm{GDPPH}, \mathrm{DISTH}, \mathrm{AERH}, \mathrm{UEH})$

where

$\mathrm{UEH}=\mathrm{employment}$ (number) in majority-owned nonbank affiliates of nonbank U.S. parents (data from U.S. Bureau of Economic Analysis, 1992, 1998), and all other notation is as defined in equation (1a) above. In general, economic activity in affiliates of competing U.S. MNCs is expected to be negatively related to Japanese export levels, so we expect the coefficients on UEH to be negative.

Equation (2a) is estimated only for 1989 and 1995. As in the previous section, Table 2 reports coefficients on employment in Japanese and U.S. affiliates, the significance levels of these coefficients, and the adjusted R-squared values for OLS estimates of equations (see Appendix Table A2 for details). U.S. affiliate variables are available for relatively small samples (41-48 countries), but the difference in sample size does not seem to have a substantial effect on the coefficients, probably because the additional countries in the larger 
sample are mostly insignificant with respect to both exports and affiliate employment. ${ }^{9}$ It is possible to estimate equation (2a) for only 5 industries instead of 9. Despite these differences, the addition of the U.S. affiliate variable in equation (2a) does not affect the direction of the relationship between Japanese exports and economic activity in Japanese affiliates, although some of the coefficients are smaller.

More specifically, in equation (2a), coefficients on Japanese affiliate employment are positive in all cases and statistically significant in most (Table 2). The coefficients on U.S. affiliate employment are generally negative, suggesting that U.S. affiliate production in a market competes with Japanese exports, while Japanese affiliate production does not at least on net balance. This relationship is similar to that found among U.S. affiliate production in a country and imports by that country from the United States and from other countries in Lipsey and Weiss (1981).

The negative coefficients for U.S. affiliate employment here are significant in metals for both years and in chemicals in 1989. However, negative U.S. affiliate coefficients in the other industries are not statistically significant. The coefficient on U.S. employment in transportation equipment is positive and significant in 1989, contrary to expectations, but that relationship mostly disappeared by 1995. Perhaps a greater presence of U.S. assembly affiliates in 1989 created a market for Japanese parts and other products. Another possibility is that the coefficients for this industry may be affected by the fact that some reported U.S.-owned production may be by

\footnotetext{
${ }^{9}$ Lipsey, Ramstetter, and Blomström, (2000b, Appendix Table A2) also estimate equations (1a) to (1c) using these smaller samples and the results are very similar to results obtained in the larger samples and reported above.
} 
U.S. affiliates of Japanese parents and some Japanese exports may be by U.S.-owned Japanese firms.

4. Changes in Japanese export levels

It is now possible to perform much more reliable analyses of the relationship between changes in exports during a given period and affiliate activity by using the revised employment estimates based on the panel data underlying Fukao, Yuan, and Sakishita (1999). This is because the panel data underlying Fukao, Yuan, and Sakishita (1999) correct many of the coverage problems present in the original MITI data, where survey response rates vary greatly over time. Following Blomström, Lipsey, and Kulchycky (1988), two relationships are examined in this respect. One is the relationship between changes in Japanese exports during a period and foreign affiliate activity in the initial year of the period. The possibility explored in that case is that a larger affiliate presence discourages the growth of parent exports, even if it is associated with a higher level of parent exports. The other is the relationship between changes in Japanese exports and changes in foreign affiliate activity during a period.

When examining these relationships, the effects of three other factors that may influence changes in exports are included. The first is the change in partner economy GDP, the second is the level of Japanese exports to the partner in the initial year, and the third is the change in the ratio of Japanese export prices to the GDP deflator in the partner economy. The resulting equations are as follows:

(1b) JXHy2-JXHy1 = fle(GDPHy2-GDPHy1, JXHy1, gPXJPH, AERHy1) 
(1c) JXHy2-JXHy1 = flf(GDPHy2-GDPHy1, JXHy1, gPXJPH, AERHy2-AERHy1)

where

gPXJPH $=$ the percentage change in the ratio of Japanese export prices (in yen) to the GDP deflator of the

partner economy (in yen, translated from partner currency at annual average exchange rates; calculated from

International Monetary Fund 2000, International Centre for the Study of East Asian Development 2000, World

Bank 1999),

y2 $=$ postscript indicating year 2,

$\mathrm{yl}=$ postscript indicating year 1 ,

and all other notation is as defined for equation (1a) above.

In general, the coefficients on the change in partner GDP and on initial exports are expected to be positive. Estimation results (see Appendix Tables A3 and A4 for details) are mixed in this respect, however.

Coefficients on the change in partner GDP are often insignificant, while coefficients on initial exports are negative and significant in several cases. In other words, the change in Japanese exports has generally been smaller in countries where Japanese exports were larger in the initial year. Coefficients on the price variable are more in line with expectations, being negative in most cases and significant in several equations.

Table 3 summarizes the most important results of these equations, showing coefficients on measures of initial Japanese affiliate activity and changes in activity. The relationship between changes in Japanese exports and affiliate employment in the initial year (equation (1b)) was most often statistically insignificant, but 
the seven statistically significant coefficients were all positive, as were almost all the other coefficients. Changes in Japanese affiliate employment were positively related to changes in Japanese exports more consistently (equation (1c)). Half the coefficients were statistically significant and all of those were positive. Thus there is no evidence that greater affiliate activity or faster growth in affiliate activity competes with the growth of Japanese exports.

A potential problem with the OLS estimates of equations (1a), (1b), and (1c) is the possibility that Japan's exports and the economic activities of Japanese affiliates are jointly determined. This is possible partially because a large portion of Japan's exports are from Japanese MNC parents (e.g., Lipsey, Ramstetter, and Blomström, 1999, Appendix Table C1) and decisions by Japanese MNCs about the level of exports from Japan and the level of affiliate activity are likely to be interdependent. Accordingly, in previous research, Swedenborg (1979) and Blomström, Lipsey, and Kulchycky (1988) used two-stage least squares (2SLS) to estimate similar equations. We have attempted similar 2SLS estimates of equations (1a), (1b), and (1c). Unfortunately, we have been unable to find a suitable set of instruments. Thus, the 2SLS results were thus very poor and are not reported here. ${ }^{10}$

\footnotetext{
${ }^{10}$ For additional instruments not included in the equations already, we tried some of the governance indicators from Kaufman, Kraay, and Zoido-Lobatón, (1999).
} 
5. The Growth of Japan's Manufacturing Exports and Affiliates of Competing MNCs

Just as the greater presence of U.S. affiliates tended to reduce Japanese exports to a host country, it might also diminish possibilities for Japanese export growth, and more rapid growth of U.S. affiliates might have the same effect. These possibilities are tested in equations (2b) and (2c) for the one available period, 1989-1995.

(2b) JXHy2-JXHy1 = f2e(GDPHy2-GDPHy1, JXHy1, gPXJPH, AERHy1, UEHy1)

(2c) JXHy2-JXHy1 = f2f(GDPHy2-GDPHy1, JXHy1, gPXJPH, AERHy2-AERHy1, UEHy2-UEHy1)

In equation (2b) explaining the relationship between changes in Japanese exports and initial year employment, coefficients were all positive for Japanese affiliate initial employment and negative for U.S. affiliate initial employment (Table 4). Only one of the positive coefficients for Japanese affiliate employment was significant (electric machinery). However, the negative coefficients for U.S. affiliate employment were significant in 3 of the 5 industries. Results from estimating the relationship between changes in Japanese exports and changes in affiliate employment in equation (2c) were consistent in that coefficients on changes in Japanese affiliate employment were all positive again, but only one was statistically significant at the conventional 5 percent level. In contrast, coefficients on changes in U.S. affiliate employment were never significant or close to it. Thus, although relatively large levels of U.S. affiliate activity often appear negatively correlated with Japanese export levels and changes in Japanese exports, changes in U.S. affiliate activity appear largely unrelated to changes in Japanese exports. 


\section{Conclusions}

The evidence here is strong that greater activity of Japanese MNCs in a host country, as represented by affiliate employment, is associated with larger exports to that country from Japan. That is true aside from standard gravity model influences on exports such as importing country size, per capita income, and distance

from Japan. We are inclined to interpret this relationship as indicating that affiliate production, which is one aspect of the contest among exporting countries and their firms for foreign markets, raises home country exports.

The usual objection to interpreting this positive relationship in this way is that there are always omitted country characteristics, such as openness, good government, or legal institutions, which simultaneously encourage inward investment and imports. If that were the main explanation for the positive relationship between Japanese affiliate activity and Japanese exports, Japanese exports should also be positively related to U.S. affiliate activity. However, Japanese exports are negatively related to U.S. affiliate employment. That fact suggests that it is the international rivalry for markets, rather than simultaneity problems, that accounts for the positive relationship between Japanese affiliate production and Japanese exports, a relationship found in many studies for the U.S. and Sweden, and other countries as well.

A positive relation to Japanese affiliate employment is found also for changes in Japanese exports to a country, and a negative relation to U.S. affiliate employment, confirming the idea that international rivalry for markets is the cause. Growth in Japanese affiliate employment is positively associated with growth in Japanese 
exports to a country. However, in the one period for which data on the growth of U.S. affiliate employment are available, we find no relation of Japanese export growth to U.S. affiliate employment growth. 


\section{References}

Amano, Tomofumi, Kyoji Fukao, and Mami Toyonaga, 1998. "Impact of Production Activities of Japanese Subsidiaries Abroad on Exports and Imports by their Parent Firms ", in Economic Planning Agency, ed., Foreign Direct Investment in Asia, papers and proceedings of an international symposium, 22-23 October, Tokyo: Economic Planning Agency, pp. 147-178.

Belderbos, Rene and Leo Sleuwaegen, 1994. "Exports and Direct Investment of Japanese Firms in Europe: Complements or Substitutes, Mimeograph, Rotterdam: Tinbergen Institute, Erasmus University.

Blomström, Magnus, Robert E. Lipsey, and Ksenia Kulchycky, 1988. "U.S. and Swedish Direct Investment and Exports," in Robert E. Baldwin, Editor, Trade Policy Issues and Empirical Analysis, Chicago, The University of Chicago Press, pp. 259-297.

Edward W. Sweetman Co., 1965. Marine Distance and Speed Table. New York, Edward W. Sweetman Co.

Feenstra, Robert C., Robert E. Lipsey, and Harry P. Bowen, 1997. "World Trade Flows, 1970-1992, with Production and Tariff Data", NBER Working Paper 5910. Cambridge, MA: National Bureau of Economic Research.

Fukao, Kyoji and Hun Chong, 1997. "Nihon Kigyou no Kaigai Seisan Katsudou to Boueki Kouzou(Overseas Production Activities by Japanese Firms and Japan's Trade Structure)", in Kazumi Asako and Masayuki Ohtaki, eds., Gendai Makuro Keizai Dougaku (Macroeconomic Dynamics). Tokyo: University of Tokyo Press.

Fukao, Kyoji, Tangjun Yuan, and Makoto Sakishita, 1999. "Kohyou no Paneruka to Nai-Gaisou ni yoru Kaigai Jigyou Katsudou Kihon Chousa, Doukou Chousa no Boushudan Suikei (Estimating Total Overseas Business Activities of Japanese Companies from Extrapolations of Panel Data Underlying the Basic and Annual Surveys)", in Institute for International Trade and Investment, ed., 1999, pp. 3-34 (in Japanese).

Institute for International Trade and Investment, ed., 1999, Kaigai Jigyou Katsudou Chousa Deta ni Mototsuku Bunseki Kenkyu, Heisei 10 Nendo no Kaigai Jigyou Katsudou Chousa Guroobarizeshon Enkatsuka Chousa Kenkyu [Analytical Research Based on Data from the Survey of Overseas Business Activities, Survey Research on Harmonizing Globalization based on the 1997 Survey of Overseas Business Activities], Tokyo: Institute for International Trade and Investment. 
Institute for International Trade and Investment, ed., 2000. Kaigai Jigyou Katsudou Chousa Deta nado ni Mototsuku Bunseki Kenkyu, Heisei 11 Nendo no Guroobarizeshon Enkatsuka Chousa Kenkyu, Kaigai Jigyou Katsudou Chousa (Analytical Research Based on Data from the Survey of Overseas Business Activities, Survey Research on Harmonizing Globalization based on the 1998 Survey of Overseas Business Activities), Tokyo: Institute for International Trade and Investment.

Institute for International Trade and Investment, ed., 2001. Kaigai Jigyou Katsudou Chousa, Gaishikei Kigyou Katsudou no Doukou De-ta nado ni Mototsuku Bunseki Kenkyuu (Analytical Research Based on Trends in Data from the Survey of Overseas Business Activities and the Survey of Foreign Affiliates' Business Activities). Tokyo: Institute for International Trade and Investment

International Centre for the Study of East Asian Development, 2000. "Recent Trends and Prospects for Major Asian Economies", East Asian Economic Perspectives, Vol. 11, Special Issue (February).

International Monetary Fund, 2000. International Financial Statistics, February CD-ROM. Washington, D.C.: International Monetary Fund.

Kaufman, Daniel, Aart Kraay, and Pablo Zoido-Lobatón, 1999. "Aggregating Governance Indicators", World Bank Policy Research Working Paper No. 2195 and underlying data downloaded from the World Bank website (http://www.worldbank.org/research/growth/corrupt_data.htm). Washington, D.C.: World Bank.

Lipsey, Robert E., Eric Ramstetter, and Magnus Blomström, 1999. " Parent Exports and Affiliate Activity in Japanese Multinational Companies, 1986, 1989, 1992", in Japan, Institute for International Trade and Investment, 1999, pp. 93-146.

Lipsey, Robert E., Eric Ramstetter, and Magnus Blomström, 2000a. "Japan's Exports and Affiliates of Japanese Multinational Corporations, 1986-1995" in Institute for International Trade and Investment, ed., 2000, pp. 50-97.

Lipsey, Robert E., Eric Ramstetter, and Magnus Blomström, 2000b. "Outward FDI and Parent Exports and Employment: Japan, the United States, and Sweden", Global Economy Quarterly, Vol. 1, No. 4.

Lipsey, Robert E., and Merle Yahr Weiss, 1981. "Foreign Production and Exports in Manufacturing Industries," Review of Economics and Statistics, Vol. LXIII, No. 4, November, pp. 488-494. 
Ministry of International Trade and Industry, various years. Kaigai Jigyou Katsudou Kihon Chousa: Kaigai Toushi Toukei Souran (The Basic Survey of Overseas Business Activities of Japanese Companies: A Comprehensive Compilation of Foreign Investment Statistics), No. 3 (1987 survey of 1986 data), No. 4 (1990 survey of 1989 data), No. 5 (1993 survey of 1992 data). Tokyo: Keibun--No. 3; Ministry of Finance Printing Bureau--No. 4, 5 (in Japanese).

Ministry of International Trade and Industry, 1998. Wagakuni Kikyou no Kaigai Jigyou Katsudou: Hesei 8 Nen Kaigai Jigyou Katsudou Kihon Chousa (Dai 6 kai) (Overseas Business Activities of Japanese Companies: The 1996 Basic Survey of Overseas Business Activities [No. 6]), 1996 survey of 1995 data. Tokyo: Ministry of Finance Printing Bureau (in Japanese).

Ministry of International Trade and Industry, 2000. Unpublished firm-level data underlying Ministry of International Industry and Trade (various years, 1998) and unpublished panel data underlying compilations by Fukao, Yuan, and Sakishita (1999).

Penn World Tables, 1995. Penn World Tables version 5.6. prepared by Alan Heston, Robert Summers, Daniel A. Nuxoll, and Bettina Aten and downloaded from the University of Toronto web site (http://cansim.epas.utoronto.ca:5680/pwt/pwt.html).

Ramstetter, Eric D., 1997. "Export Performance and Foreign Affiliate Activity in Japan's Large Machinery Firms", Transnational Corporations, Vol 6, No. 3 (December), pp. 113-133.

Ramstetter, Eric D., 2001. "Parent Exports and Affiliate Activity in Japanese Multinational Corporations Revisited" in Institute for International Trade and Investment, 2001, pp. 19-64.

Statistics Canada, 1999. World Trade Analyzer, CD-ROM. Ottawa: Statistics Canada.

Swedenborg, Birgitta, 1979. The Multinational Operations of Swedish Firms: Determinants and Effects. Stockholm, The Industrial Institute for Economic and Social Research (IUI).

U.S. Bureau of Economic Analysis, 1992. U.S. Direct Investment Abroad: 1989 Benchmark Survey, Final Results, data file downloaded from www.bea.gov. Washington, D.C.: Bureau of Economic Analysis.

U.S. Bureau of Economic Analysis, 1998. U.S. Direct Investment Abroad: Operations of U.S. Parent Companies and Their Foreign Affiliates Revised 1995 Estimates, data file downloaded from www.bea.gov. Washington, D.C.: Bureau of Economic Analysis. 
U.S. Navy Department, 1943. Table of Distances Between Ports, U.S. Navy Department, Hydrographic Office, Washington, D.C., GPO..

White, Halbert, 1980. "Heteroskedasticity-Consistent Covariance Matrix and a Direct Test for Heteroskedasticity", Econometrica, 48, pp. 817-838.

World Bank 1999. World Development Indicators 1999, CD-ROM. Washington, D.C.: World Bank. 
Table 1: Coefficients on Employment in Japanese Manufacturing Affiliates (AERH) and Adjusted R-squared from OLS Regressions Explaining Japanese Exports by Country (Equation (1a), Large Sample (96-98 countries)

\begin{tabular}{|c|c|c|c|c|c|c|c|c|c|c|c|c|}
\hline \multirow[b]{2}{*}{ Equation, Industry } & \multicolumn{3}{|c|}{1986 (98 countries) } & \multicolumn{3}{|c|}{1989 (98 countries) } & \multicolumn{3}{|c|}{1992 (98 countries) } & \multicolumn{3}{|c|}{1995 (96 countries) } \\
\hline & $\begin{array}{r}\text { Coeffi- } \\
\text { cients } \\
\end{array}$ & $\begin{array}{r}\text { Signifi- } \\
\text { cance } \\
\text { level } \\
\end{array}$ & $\begin{array}{r}\text { Adjus- } \\
\text { ted R- } \\
\text { squared }\end{array}$ & $\begin{array}{r}\text { Coeffi- } \\
\text { cients } \\
\end{array}$ & $\begin{array}{r}\text { Signifi- } \\
\text { cance } \\
\text { level }\end{array}$ & $\begin{array}{r}\text { Adjus- } \\
\text { ted R- } \\
\text { squared }\end{array}$ & $\begin{array}{r}\text { Coeffi- } \\
\text { cients } \\
\end{array}$ & $\begin{array}{r}\text { Signifi- } \\
\text { cance } \\
\text { level } \\
\end{array}$ & $\begin{array}{l}\text { Adjus- } \\
\text { ted R- } \\
\text { squared }\end{array}$ & $\begin{array}{r}\text { Coeffi- } \\
\text { cients } \\
\end{array}$ & $\begin{array}{r}\text { Signifi- } \\
\text { cance } \\
\text { level } \\
\end{array}$ & $\begin{array}{l}\text { Adjus- } \\
\text { ted R- } \\
\text { squared }\end{array}$ \\
\hline Food, beverages, tobacco & 2.142 & $26 \%$ & 0.66 & 1.644 & $1 \%$ & 0.48 & 1.276 & $0 \%$ & 0.51 & 0.822 & $1 \%$ & 0.50 \\
\hline Textiles, apparel, leather & 1.072 & $14 \%$ & 0.62 & 1.104 & $15 \%$ & 0.56 & 1.846 & $2 \%$ & 0.57 & 2.039 & $0 \%$ & 0.81 \\
\hline Wood, furniture, paper & -1.025 & $19 \%$ & 0.62 & 0.436 & $67 \%$ & 0.61 & 0.654 & $50 \%$ & 0.55 & 0.315 & $69 \%$ & 0.57 \\
\hline Chemicals & 12.024 & $4 \%$ & 0.72 & 9.705 & $0 \%$ & 0.70 & 9.863 & $0 \%$ & 0.73 & 10.759 & $0 \%$ & 0.74 \\
\hline Metals & -0.784 & $78 \%$ & 0.74 & 4.345 & $20 \%$ & 0.74 & 6.594 & $2 \%$ & 0.74 & 7.097 & $0 \%$ & 0.72 \\
\hline General \& precision machinery & 40.643 & $5 \%$ & 0.87 & 51.212 & $0 \%$ & 0.88 & 40.915 & $0 \%$ & 0.89 & 25.652 & $0 \%$ & 0.84 \\
\hline Electric machinery & 7.935 & $1 \%$ & 0.77 & 8.694 & $0 \%$ & 0.82 & 6.179 & $0 \%$ & 0.78 & 4.231 & $0 \%$ & 0.73 \\
\hline Transportation machinery & 11.733 & $53 \%$ & 0.70 & 26.733 & $4 \%$ & 0.76 & 16.725 & $4 \%$ & 0.78 & 11.945 & $1 \%$ & 0.74 \\
\hline Other manufacturing & 6.671 & $2 \%$ & 0.77 & 5.911 & $0 \%$ & 0.94 & 4.734 & $0 \%$ & 0.88 & 3.026 & $0 \%$ & 0.82 \\
\hline
\end{tabular}

Significance levels are calculated from t-statistics; calculations use heteroscedasticity-consistent standard errors if the White F-test for heteroscedasticity is significant at the 5\% level or less; see Appendix Table A1 for detailed results and notes.

Table 2: Coefficients on Employment in Japanese and U.S. Manufacturing Affiliates (AERH and UEH) and Adjusted R-squared from OLS Regressions Explaining Japanese Exports by Country (Equation (2a), Small Sample (41-49 countries)

\begin{tabular}{|c|c|c|c|c|c|c|c|c|c|c|}
\hline \multirow[b]{3}{*}{ Equation, Industry } & \multicolumn{5}{|c|}{1989 (41-48 countries) } & \multicolumn{5}{|c|}{1995 (49 countries) } \\
\hline & \multicolumn{2}{|c|}{ Japanese Affiliates } & \multicolumn{2}{|c|}{ U.S. Affiliates } & \multirow[b]{2}{*}{$\begin{array}{r}\text { Adjus- } \\
\text { ted R- } \\
\text { squared }\end{array}$} & \multicolumn{2}{|c|}{ Japanese Affiliates } & \multicolumn{2}{|c|}{ U.S. Affiliates } & \multirow[b]{2}{*}{$\begin{array}{l}\text { Adjus- } \\
\text { ted R- } \\
\text { squared }\end{array}$} \\
\hline & $\begin{array}{r}\text { Coeffi- } \\
\text { cients } \\
\end{array}$ & $\begin{array}{r}\text { Signifi- } \\
\text { cance } \\
\text { level } \\
\end{array}$ & $\begin{array}{r}\text { Coeffi- } \\
\text { cients }\end{array}$ & $\begin{array}{r}\text { Signifi- } \\
\text { cance } \\
\text { level } \\
\end{array}$ & & $\begin{array}{r}\text { Coeffi- } \\
\text { cients } \\
\end{array}$ & $\begin{array}{r}\text { Signifi- } \\
\text { cance } \\
\text { level } \\
\end{array}$ & $\begin{array}{r}\text { Coeffi- } \\
\text { cients } \\
\end{array}$ & $\begin{array}{r}\text { Signifi- } \\
\text { cance } \\
\text { level }\end{array}$ & \\
\hline Food, beverages, tobacco & 0.649 & $22 \%$ & -0.076 & $47 \%$ & 0.31 & 0.561 & $6 \%$ & -0.130 & $12 \%$ & 0.49 \\
\hline Chemicals & 12.956 & $2 \%$ & -0.800 & $5 \%$ & 0.63 & 8.891 & $2 \%$ & -0.132 & $82 \%$ & 0.62 \\
\hline Metals & 4.523 & $2 \%$ & -3.527 & $2 \%$ & 0.63 & 6.499 & $0 \%$ & -3.116 & $3 \%$ & 0.75 \\
\hline Electric machinery & 5.429 & $0 \%$ & 0.248 & $83 \%$ & 0.70 & 4.290 & $0 \%$ & -0.078 & $87 \%$ & 0.67 \\
\hline Transportation machinery & 2.571 & $34 \%$ & 1.738 & $1 \%$ & 0.45 & 4.918 & $2 \%$ & 0.250 & $73 \%$ & 0.24 \\
\hline
\end{tabular}

Significance levels are calculated from t-statistics; calculations use heteroscedasticity-consistent standard errors if the White F-test

for heteroscedasticity is significant at the 5\% level or less; see Appendix Table A2 for detailed results and notes.

For 1989, samples consisted of 48 countries each for food, beverages, tobacco and for chemicals, 44 countries for metals, 47 countries

for electric machinery and 41 countries for transportation machinery. 
Table 3: Coefficients on Initial Employment and Changes in Employment of Japanese Manufacturing Affiliates and Adjusted R-squared from OLS Regressions Explaining Changes in Japanese Exports by Country, Large Sample (88-93 countries)

\begin{tabular}{|c|c|c|c|c|c|c|c|c|c|}
\hline \multirow[b]{2}{*}{ Equation, Industry } & \multicolumn{3}{|c|}{ 1986-1989 (93 countries) } & \multicolumn{3}{|c|}{ 1989-1992 (90 countries) } & \multicolumn{3}{|c|}{ 1992-1995 (88 countries) } \\
\hline & $\begin{array}{r}\text { Coeffi- } \\
\text { cients } \\
\end{array}$ & $\begin{array}{r}\text { Signifi- } \\
\text { cance } \\
\text { level } \\
\end{array}$ & $\begin{array}{r}\text { Adjus- } \\
\text { ted R- } \\
\text { squared } \\
\end{array}$ & $\begin{array}{r}\text { Coeffi- } \\
\text { cients } \\
\end{array}$ & $\begin{array}{r}\text { Signifi- } \\
\text { cance } \\
\text { level } \\
\end{array}$ & $\begin{array}{l}\text { Adjus- } \\
\text { ted R- } \\
\text { squared } \\
\end{array}$ & $\begin{array}{r}\text { Coeffi- } \\
\text { cients } \\
\end{array}$ & $\begin{array}{r}\text { Signifi- } \\
\text { cance } \\
\text { level } \\
\end{array}$ & $\begin{array}{l}\text { Adjus- } \\
\text { ted R- } \\
\text { squared } \\
\end{array}$ \\
\hline \multicolumn{10}{|c|}{ Coefficients on initial employment of affiliates (=AERHy1) from equation (1b) } \\
\hline Food, beverages, tobacco & 0.256 & $61 \%$ & 0.36 & 0.556 & $20 \%$ & 0.03 & -0.150 & $42 \%$ & 0.54 \\
\hline Textiles, apparel, leather & 0.633 & $1 \%$ & 0.73 & 0.503 & $6 \%$ & 0.23 & 0.490 & $28 \%$ & 0.63 \\
\hline Wood, furniture, paper & 0.643 & $13 \%$ & 0.04 & -0.367 & $51 \%$ & 0.12 & 0.750 & $2 \%$ & 0.81 \\
\hline Metals & 2.696 & $21 \%$ & 0.31 & 1.142 & $24 \%$ & 0.63 & -1.487 & $26 \%$ & 0.08 \\
\hline General \& precision machinery & 10.553 & $16 \%$ & 0.74 & 12.673 & $9 \%$ & 0.40 & 9.595 & $0 \%$ & 0.44 \\
\hline Electric machinery & 4.036 & $0 \%$ & 0.69 & 2.606 & $0 \%$ & 0.26 & 2.923 & $0 \%$ & 0.46 \\
\hline Transportation machinery & 5.643 & $3 \%$ & 0.93 & 0.152 & $91 \%$ & 0.49 & 2.434 & $18 \%$ & 0.71 \\
\hline Other manufacturing & 2.281 & $7 \%$ & 0.28 & -0.645 & $59 \%$ & 0.10 & 0.555 & $25 \%$ & 0.38 \\
\hline \multicolumn{10}{|c|}{ Coefficients on the change in employment of affiliates (=AERHy2-AERHy1) from equation (1c) } \\
\hline Food, beverages, tobacco & -0.996 & $56 \%$ & 0.37 & 0.722 & $14 \%$ & 0.01 & 0.555 & $20 \%$ & 0.55 \\
\hline Wood, furniture, paper & 3.567 & $11 \%$ & 0.17 & 1.719 & $0 \%$ & 0.15 & -0.157 & $80 \%$ & 0.75 \\
\hline Chemicals & 0.757 & $70 \%$ & 0.69 & 2.038 & $30 \%$ & 0.61 & 3.657 & $0 \%$ & 0.75 \\
\hline Metals & 12.153 & $3 \%$ & 0.39 & 4.026 & $31 \%$ & 0.63 & 6.223 & $11 \%$ & 0.16 \\
\hline General \& precision machinery & 26.639 & $0 \%$ & 0.80 & 7.807 & $1 \%$ & 0.19 & 6.512 & $27 \%$ & 0.30 \\
\hline Electric machinery & 2.907 & $0 \%$ & 0.36 & 3.102 & $8 \%$ & 0.16 & 4.956 & $0 \%$ & 0.40 \\
\hline Transportation machinery & 12.105 & $0 \%$ & 0.94 & 2.774 & $20 \%$ & 0.50 & 8.593 & $2 \%$ & 0.72 \\
\hline Other manufacturing & -1.268 & $19 \%$ & 0.11 & 4.150 & $0 \%$ & 0.38 & 1.101 & $17 \%$ & 0.39 \\
\hline
\end{tabular}

Significance levels are calculated from t-statistics; calculations use heteroscedasticity-consistent standard errors if the White F-test for heteroscedasticity is significant at the 5\% level or less; see Appendix Table A3 for detailed results and notes. 
Table 4: Coefficients on Initial Employment and Changes in Employment of Japanese and U.S. Manufacturing Affiliates and Adjusted R-squared from OLS Regressions Explaining Changes in Japanese Exports by Country, 1989-1995, Small Sample (41-48 countries)

\begin{tabular}{|c|c|c|c|c|c|}
\hline \multirow[b]{2}{*}{ Equation, Industry } & \multicolumn{2}{|c|}{ Japanese Affiliates } & \multicolumn{2}{|c|}{ U.S. Affiliates } & \multirow[b]{2}{*}{$\begin{array}{c}\text { Adjus- } \\
\text { ted R- } \\
\text { squared }\end{array}$} \\
\hline & $\begin{array}{r}\text { Coeffi- } \\
\text { cients }\end{array}$ & $\begin{array}{r}\text { Signifi- } \\
\text { cance } \\
\text { level }\end{array}$ & $\begin{array}{r}\text { Coeffi- } \\
\text { cients }\end{array}$ & $\begin{array}{r}\text { Signifi- } \\
\text { cance } \\
\text { level }\end{array}$ & \\
\hline \multicolumn{6}{|c|}{ Coefficients on initial revised employment of affiliates (=AERHy1, UEHy1) from equation (2b) } \\
\hline Food, beverages, tobacco (48 countries) & 0.902 & $17 \%$ & -0.122 & $3 \%$ & 0.37 \\
\hline Chemicals (48 countries) & 2.799 & $21 \%$ & -0.279 & $1 \%$ & 0.60 \\
\hline Metals (43 countries) & 1.468 & $13 \%$ & -0.417 & $14 \%$ & 0.35 \\
\hline Electric machinery (47 countries) & 5.148 & $3 \%$ & -0.673 & $54 \%$ & 0.45 \\
\hline Transportation machinery (41 countries) & 3.201 & $13 \%$ & -1.491 & $1 \%$ & 0.14 \\
\hline \multicolumn{6}{|c|}{ Coefficients on the change in revised employment of affiliates (=AERHy2-AERHy1, UEHy2-UEHy1) from equation (2c) } \\
\hline Food, beverages, tobacco (48 countries) & 0.417 & $18 \%$ & -0.049 & $58 \%$ & 0.21 \\
\hline Chemicals (48 countries) & 3.107 & $6 \%$ & 0.537 & $28 \%$ & 0.58 \\
\hline Metals (43 countries) & 3.171 & $13 \%$ & -1.131 & $42 \%$ & 0.40 \\
\hline Electric machinery (47 countries) & 3.323 & $2 \%$ & 0.605 & $54 \%$ & 0.48 \\
\hline Transportation machinery (41 countries) & 3.683 & $11 \%$ & 2.265 & $30 \%$ & 0.07 \\
\hline
\end{tabular}

Significance levels are calculated from t-statistics; calculations use heteroscedasticity-consistent standard errors if the White F-test

for heteroscedasticity is significant at the 5\% level or less; see Appendix Table A4 for detailed results and notes. 
Appendix Table A1: OLS Regressions Explaining Japanese Exports to a Country by Employment of Japanese

Manufacturing Affiliates and Other Variables (Equation (1a), Large Sample (96-98 countries)

\begin{tabular}{|c|c|c|c|c|c|c|c|c|c|c|c|c|}
\hline \multirow[b]{2}{*}{$\begin{array}{l}\text { Dependent variable, } \\
\text { independent variables, } \\
\text { equation statistics }\end{array}$} & \multicolumn{3}{|c|}{1986 (98 countries) } & \multicolumn{3}{|c|}{1989 (98 countries) } & \multicolumn{3}{|c|}{1992 (98 countries) } & \multicolumn{3}{|c|}{1995 (96 countries) } \\
\hline & $\begin{array}{r}\text { Coeffi- } \\
\text { cients, } \\
\text { etc. }\end{array}$ & $\begin{array}{r}\text { signit1- } \\
\text { cance } \\
\text { level, } \\
\text { OLS }\end{array}$ & $\begin{array}{r}\text { Signit1- } \\
\text { cance } \\
\text { level, } \\
\text { White }\end{array}$ & $\begin{array}{r}\text { Coeffi- } \\
\text { cients, } \\
\text { etc. }\end{array}$ & $\begin{array}{r}\text { Signit1- } \\
\text { cance } \\
\text { level, } \\
\text { OLS }\end{array}$ & $\begin{array}{r}\text { Signit1- } \\
\text { cance } \\
\text { level, } \\
\text { White }\end{array}$ & $\begin{array}{r}\text { Coeffi- } \\
\text { cients, } \\
\text { etc. }\end{array}$ & $\begin{array}{r}\text { Signifi- } \\
\text { cance } \\
\text { level, } \\
\text { OLS }\end{array}$ & $\begin{array}{r}\text { Signit1- } \\
\text { cance } \\
\text { level, } \\
\text { White }\end{array}$ & $\begin{array}{r}\text { Coeffi- } \\
\text { cients, } \\
\text { etc. }\end{array}$ & $\begin{array}{r}\text { Signit1- } \\
\text { cance } \\
\text { level, } \\
\text { OLS }\end{array}$ & $\begin{array}{r}\text { Signit1- } \\
\text { cance } \\
\text { level, } \\
\text { White }\end{array}$ \\
\hline \multicolumn{13}{|c|}{ Food, beverages, tobacco } \\
\hline Constant (thousands) & 3.202 & 0.077 & 0.274 & 5.329 & 0.006 & 0.119 & 4.684 & 0.016 & 0.101 & 4.832 & 0.005 & 0.064 \\
\hline GDPH & 0.050 & 0.000 & 0.019 & 0.011 & 0.101 & 0.177 & 0.007 & 0.263 & 0.423 & 0.001 & 0.885 & 0.917 \\
\hline GDPPH & 1.562 & 0.009 & 0.015 & 1.432 & 0.010 & 0.029 & 1.777 & 0.001 & 0.065 & 1.427 & 0.001 & 0.033 \\
\hline DISTH & -0.594 & 0.003 & 0.077 & -0.738 & 0.000 & 0.069 & -0.717 & 0.001 & 0.065 & -0.691 & 0.000 & 0.033 \\
\hline AERH & 2.142 & 0.011 & 0.257 & 1.644 & 0.001 & 0.011 & 1.276 & 0.000 & 0.005 & 0.822 & 0.001 & 0.014 \\
\hline F-statistic & 47.041 & 0.000 & 0.000 & 23.307 & 0.000 & 0.000 & 26.184 & 0.000 & 0.000 & 24.924 & 0.000 & 0.000 \\
\hline F-White (Hetero.) & 17.425 & 0.000 & 0.000 & 3.630 & 0.001 & 0.001 & 4.604 & 0.000 & 0.000 & 6.188 & 0.000 & 0.000 \\
\hline Adjusted R-squared & 0.655 & & & 0.479 & - & - & 0.509 & - & - & 0.502 & - & \\
\hline \multicolumn{13}{|c|}{ Textiles, apparel, leather } \\
\hline Constant (thousands) & 23.090 & 0.001 & 0.005 & 21.290 & 0.000 & 0.008 & 20.466 & 0.004 & 0.010 & 6.932 & 0.112 & 0.089 \\
\hline GDPH & 0.160 & 0.000 & 0.000 & 0.077 & 0.000 & 0.000 & 0.052 & 0.003 & 0.008 & 0.025 & 0.012 & 0.026 \\
\hline GDPPH & 6.499 & 0.002 & 0.022 & 5.336 & 0.001 & 0.033 & 6.191 & 0.001 & 0.048 & 3.069 & 0.003 & 0.025 \\
\hline DISTH & -3.199 & 0.000 & 0.003 & -2.856 & 0.000 & 0.006 & -2.934 & 0.000 & 0.010 & -1.175 & 0.009 & 0.025 \\
\hline AERH & 1.072 & 0.025 & 0.140 & 1.104 & 0.008 & 0.154 & 1.846 & 0.000 & 0.018 & 2.039 & 0.000 & 0.000 \\
\hline F-statistic & 40.605 & 0.000 & 0.000 & 31.655 & 0.000 & 0.000 & 32.999 & 0.000 & 0.000 & 102.630 & 0.000 & 0.000 \\
\hline F-White (Hetero.) & 3.800 & 0.001 & 0.001 & 3.057 & 0.004 & 0.004 & 5.239 & 0.000 & 0.000 & 52.539 & 0.000 & 0.000 \\
\hline Adjusted R-squared & 0.620 & - & - & 0.558 & - & - & 0.569 & - & - & 0.811 & - & - \\
\hline \multicolumn{13}{|l|}{ Wood, furniture, paper } \\
\hline Constant (thousands) & 8.288 & 0.000 & 0.002 & 6.680 & 0.000 & 0.024 & 9.791 & 0.000 & 0.008 & 8.368 & 0.000 & 0.006 \\
\hline GDPH & 0.042 & 0.000 & 0.000 & 0.039 & 0.000 & 0.006 & 0.034 & 0.000 & 0.001 & 0.023 & 0.000 & 0.003 \\
\hline GDPPH & 1.200 & 0.017 & 0.074 & 1.980 & 0.000 & 0.016 & 2.317 & 0.000 & 0.041 & 1.783 & 0.000 & 0.019 \\
\hline DISTH & -1.030 & 0.000 & 0.001 & -0.978 & 0.000 & 0.008 & -1.351 & 0.000 & 0.005 & -1.123 & 0.000 & 0.003 \\
\hline AERH & -1.025 & 0.248 & 0.190 & 0.436 & 0.545 & 0.668 & 0.654 & 0.478 & 0.503 & 0.315 & 0.599 & 0.688 \\
\hline F-statistic & 40.575 & 0.000 & 0.000 & 38.702 & 0.000 & 0.000 & 31.084 & 0.000 & 0.000 & 33.001 & 0.000 & 0.000 \\
\hline F-White (Hetero.) & 4.155 & 0.000 & 0.000 & 3.966 & 0.000 & 0.000 & 4.670 & 0.000 & 0.000 & 6.596 & 0.000 & 0.000 \\
\hline Adjusted R-squared & 0.620 & & & 0.609 & - & - & 0.554 & - & - & 0.574 & - & \\
\hline \multicolumn{13}{|l|}{ Chemicals } \\
\hline Constant (thousands) & 27.966 & 0.001 & 0.021 & 39.318 & 0.000 & 0.013 & 41.868 & 0.000 & 0.016 & 43.846 & 0.002 & 0.045 \\
\hline GDPH & 0.169 & 0.000 & 0.003 & 0.031 & 0.469 & 0.720 & 0.006 & 0.900 & 0.947 & -0.011 & 0.827 & 0.915 \\
\hline GDPPH & 4.998 & 0.055 & 0.021 & 6.345 & 0.032 & 0.005 & 8.710 & 0.005 & 0.005 & 10.965 & 0.001 & 0.005 \\
\hline DISTH & -3.667 & 0.000 & 0.005 & -4.702 & 0.000 & 0.005 & -5.346 & 0.000 & 0.006 & -5.950 & 0.000 & 0.018 \\
\hline AERH & 12.024 & 0.000 & 0.042 & 9.705 & 0.000 & 0.002 & 9.863 & 0.000 & 0.001 & 10.759 & 0.000 & 0.003 \\
\hline F-statistic & 62.206 & 0.000 & 0.000 & 57.598 & 0.000 & 0.000 & 66.514 & 0.000 & 0.000 & 67.039 & 0.000 & 0.000 \\
\hline F-White (H & 12.655 & 0.000 & 0.000 & 9.393 & 0.000 & 0.000 & 11.167 & 0.000 & 0.000 & 9.573 & 0.000 & 0.000 \\
\hline Adjusted R-squared & 0.716 & - & - & 0.700 & - & - & 0.730 & - & - & 0.735 & - & - \\
\hline \multicolumn{13}{|l|}{ Metals } \\
\hline Constant (thousands) & 90.226 & 0.000 & 0.007 & 79.874 & 0.000 & 0.002 & 61.255 & 0.000 & 0.004 & 63.376 & 0.000 & 0.006 \\
\hline GDPH & 0.737 & 0.000 & 0.000 & 0.397 & 0.000 & 0.000 & 0.158 & 0.000 & 0.028 & 0.046 & 0.249 & 0.470 \\
\hline GDPPH & -3.061 & 0.568 & 0.632 & 3.949 & 0.342 & 0.343 & 7.477 & 0.024 & 0.040 & 8.241 & 0.011 & 0.029 \\
\hline DISTH & -9.755 & 0.000 & 0.002 & -9.418 & 0.000 & 0.001 & -7.567 & 0.000 & 0.003 & -7.748 & 0.000 & 0.003 \\
\hline AERH & -0.784 & 0.611 & 0.784 & 4.345 & 0.001 & 0.200 & 6.594 & 0.000 & 0.018 & 7.097 & 0.000 & 0.000 \\
\hline F-statistic & 69.344 & 0.000 & 0.000 & 70.979 & 0.000 & 0.000 & 69.864 & 0.000 & 0.000 & 63.283 & 0.000 & 0.000 \\
\hline F-White $(\mathrm{H}$ & 9.897 & 0.000 & 0.000 & 14.350 & 0.000 & 0.000 & 6.063 & 0.000 & 0.000 & 16.856 & 0.000 & 0.000 \\
\hline Adjusted R-squared & 0.738 & - & - & 0.743 & - & - & 0.740 & - & - & 0.724 & - & - \\
\hline
\end{tabular}


Table A1 (continued, 2/2)

\begin{tabular}{|c|c|c|c|c|c|c|c|c|c|c|c|c|}
\hline \multirow[b]{2}{*}{$\begin{array}{l}\text { Dependent variable, } \\
\text { independent variables, } \\
\text { equation statistics }\end{array}$} & \multicolumn{3}{|c|}{1986 (98 observations) } & \multicolumn{3}{|c|}{1989 (98 observations) } & \multicolumn{3}{|c|}{1992 (98 observations) } & \multicolumn{3}{|c|}{1995 (96 observations) } \\
\hline & $\begin{array}{r}\text { Coeffi- } \\
\text { cients, } \\
\text { etc. }\end{array}$ & $\begin{array}{r}\text { cance } \\
\text { caviti- } \\
\text { OLS }\end{array}$ & $\begin{array}{l}\text { Signit1- } \\
\text { cance } \\
\text { level, } \\
\text { White }\end{array}$ & $\begin{array}{r}\text { Coeffi- } \\
\text { cients, } \\
\text { etc. }\end{array}$ & $\begin{array}{r}\text { Signit1- } \\
\text { cance } \\
\text { level, } \\
\text { OLS }\end{array}$ & $\begin{array}{r}\text { Signit1- } \\
\text { cance } \\
\text { level, } \\
\text { White }\end{array}$ & $\begin{array}{r}\text { Coeffi- } \\
\text { cients, } \\
\text { etc }\end{array}$ & $\begin{array}{r}\text { Signit1- } \\
\text { cance } \\
\text { level, } \\
\text { OLS }\end{array}$ & $\begin{array}{r}\text { Signif1- } \\
\text { cance } \\
\text { level, } \\
\text { White }\end{array}$ & $\begin{array}{r}\text { Coeffi- } \\
\text { cients, } \\
\text { etc. }\end{array}$ & $\begin{array}{r}\text { Signit1- } \\
\text { cance } \\
\text { level, } \\
\text { OLS }\end{array}$ & $\begin{array}{r}\text { Signit1- } \\
\text { cance } \\
\text { level, } \\
\text { White }\end{array}$ \\
\hline \multicolumn{7}{|c|}{ All machinery (general, electric, tranportation, and precision) combined } & & & & & & \\
\hline Constant (thousands) & -231.961 & 0.257 & 0.348 & -390.292 & 0.026 & 0.113 & -248.330 & 0.138 & 0.286 & -129.782 & 0.476 & 0.530 \\
\hline GDPH & 8.437 & 0.000 & 0.005 & 5.120 & 0.000 & 0.014 & 4.803 & 0.000 & 0.007 & 4.305 & 0.000 & 0.008 \\
\hline GDPPH & 93.754 & 0.143 & 0.052 & 93.970 & 0.048 & 0.007 & 125.569 & 0.003 & 0.003 & 133.970 & 0.001 & 0.012 \\
\hline DISTH & -2.377 & 0.914 & 0.928 & 17.962 & 0.340 & 0.466 & 1.375 & 0.938 & 0.951 & -12.012 & 0.526 & 0.524 \\
\hline AERH & 16.887 & 0.001 & 0.081 & 20.096 & 0.000 & 0.006 & 13.433 & 0.000 & 0.004 & 7.370 & 0.000 & 0.001 \\
\hline F-statist & 82.278 & 0.000 & 0.000 & 108.768 & 0.000 & 0.000 & 110.685 & 0.000 & 0.000 & 88.580 & 0.000 & 0.000 \\
\hline F-Whit & 56.195 & 0.000 & 0.000 & 71.438 & 0.000 & 0.000 & 86.634 & 0.000 & 0.000 & 61.169 & 0.000 & 0.000 \\
\hline Adjusted & 0.770 & $\begin{array}{lll}- & - \\
\end{array}$ & & 0.816 & & & 0.819 & & & 0.787 & & \\
\hline \multicolumn{13}{|c|}{ General \& precision machinery } \\
\hline Constan & 8.839 & 0.807 & 0.857 & -45.269 & 0.301 & 0.511 & -40.890 & 0.335 & 0.490 & -10.744 & 0.843 & 0.892 \\
\hline GDPH & 1.601 & 0.000 & 0.007 & 1.285 & 0.000 & 0.017 & 1.125 & 0.000 & 0.021 & 1.351 & 0.000 & 0.006 \\
\hline GD & 23.204 & 0.061 & 0.038 & 22.415 & 0.087 & 0.090 & 33.548 & 0.004 & 0.005 & 35.513 & 0.007 & 0.020 \\
\hline DIS & -6.198 & 0.119 & 0.374 & -0.936 & 0.844 & 0.918 & -1.875 & 0.682 & 0.776 & -6.382 & 0.269 & 0.422 \\
\hline $\mathrm{H}$ & .643 & 0.000 & 0.051 & 51.212 & 0.000 & 0.004 & 40.915 & 0.000 & 0.002 & 25.652 & 0.000 & 0.002 \\
\hline F-statistic & 170.041 & 0.000 & 0.000 & 182.863 & 0.000 & 0.000 & 199.520 & 0.000 & 0.000 & 127.568 & 0.000 & 0.000 \\
\hline $\mathrm{F}-\mathrm{I}$ & .498 & 0.000 & 0.000 & 15.849 & 0.000 & 0.000 & 29.940 & 0.000 & 0.000 & 37.646 & 0.000 & 0.000 \\
\hline Adjusted R-sq & 0.875 & - & - & 0.882 & - & - & 0.891 & - & - & 0.842 & - & - \\
\hline \multicolumn{13}{|l|}{ Electric machinery } \\
\hline Con & 1.359 & 0.434 & 0.512 & -62.763 & 0.166 & 0.261 & -16.478 & 0.739 & 0.786 & 15.158 & 0.804 & 0.808 \\
\hline GD & 2.188 & 000 & 0.004 & 1.397 & 0.000 & 0.006 & 1.291 & 0.000 & 0.006 & 1.136 & 0.000 & 0.015 \\
\hline & 32.108 & 0.054 & 0.020 & 34.475 & 0.005 & 0.002 & 45.158 & 0.000 & 0.005 & 54.735 & 0.000 & 0.011 \\
\hline & -3.070 & 0.591 & 0.661 & -0.189 & 0.969 & 0.974 & -6.447 & 0.221 & 0.331 & -10.955 & 0.086 & 0.123 \\
\hline $\mathrm{Al}$ & 7.935 & 0.000 & 0.006 & 8.694 & 0.000 & 0.000 & 6.179 & 0.000 & 0.003 & 4.231 & 0.000 & 0.001 \\
\hline F-s & 83.938 & 0.000 & 0.000 & 110.731 & 0.000 & 0.000 & 88.520 & 0.000 & 0.000 & 66.286 & 0.000 & 0.000 \\
\hline & 809 & 0.000 & 0.000 & 40.013 & 0.000 & 0.000 & 35.315 & 0.000 & 0.000 & 26.597 & 0.000 & 0.000 \\
\hline Adjusted & 774 & - & - & 0.819 & - & - & 0.783 & 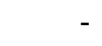 & - & 0.733 & - & . \\
\hline \multicolumn{13}{|c|}{ Transportation machinery } \\
\hline Cons & -101.981 & 0.372 & 0.448 & -201.183 & 0.012 & 0.056 & -163.245 & 0.023 & 0.113 & -178.510 & 0.012 & 0.124 \\
\hline & 4.436 & 0.000 & 0.010 & 1.981 & 0.000 & 0.042 & 1.807 & 0.000 & 0.021 & 1.214 & 0.000 & 0.073 \\
\hline & 40.882 & 0.245 & 0.136 & 31.387 & 0.152 & 0.055 & 42.965 & 0.018 & 0.008 & 34.910 & 0.026 & 0.048 \\
\hline & -2.617 & 829 & 0.849 & .904 & 0.161 & 0.230 & 8.500 & 0.258 & 0.366 & 11.495 & 0.113 & 0.259 \\
\hline AERH & 11.733 & 0.317 & 0.533 & 26.733 & 0.000 & 0.041 & 16.725 & 0.000 & 0.037 & 11.945 & 0.000 & 0.009 \\
\hline & & 0.000 & 0.000 & 78.582 & 0.000 & 0.000 & 86.229 & 0.000 & 0.000 & 70.117 & 0.000 & 0.000 \\
\hline F-Whi & 82.010 & 0.000 & 0.000 & 108.748 & 0.000 & 0.000 & 89.554 & 0.000 & 0.000 & 40.083 & 0.000 & 0.000 \\
\hline Adjusted & 704 & - & & 0.762 & - & & 0.778 & & & 0.744 & - & - \\
\hline \multicolumn{13}{|l|}{ Other manufacturing } \\
\hline & -2.653 & 0.789 & 0.829 & 19 & 0.679 & 0.770 & 4.325 & 0.502 & 0.627 & 10.814 & 0.166 & 0.386 \\
\hline GDP & 0.379 & 0.000 & 0.006 & 0.052 & 0.018 & 0.049 & 0.088 & 0.002 & 0.081 & 0.111 & 0.000 & 0.062 \\
\hline & 840 & 0.027 & 0.007 & 6.891 & 0.000 & 0.000 & 9.419 & 0.000 & 0.000 & 8.215 & 0.000 & 0.003 \\
\hline & -1.153 & 0.283 & 0.358 & -0.955 & 0.062 & 0.194 & -1.576 & 0.025 & 0.131 & -2.321 & 0.005 & 0.094 \\
\hline AERH & 6.671 & 0.000 & 0.019 & 5.911 & 0.000 & 0.000 & 4.734 & 0.000 & 0.000 & 3.026 & 0.000 & 0.001 \\
\hline & .325 & 0.000 & 0.000 & 371.150 & 0.000 & 0.000 & 181.448 & 0.000 & 0.000 & 112.928 & 0.000 & 0.000 \\
\hline F-White (H & 77.145 & 0.000 & 0.000 & 7.613 & 0.000 & 0.000 & 9.687 & 0.000 & 0.000 & 16.160 & 0.000 & 0.000 \\
\hline Adjusted R-squared & 0.768 & - & - & 0.939 & & & 0.882 & & & 0.825 & & - \\
\hline
\end{tabular}

Notes: Chemical fibers are included in textiles as is the practice in MITI publications.

Other manufacturing includes some oil and coal products; chemicals includes some oil products.

OLS=significance levels from ordinary least squares regressions.

White $=$ significance levels use White's heteroscedasticity-consistent standard errors and covariances.

F-White (Hetero.) is the F-statistic from a regression of the squares of residuals from an OLS regression on all independent variables and their squares (no cross terms included).

See Lipsey, Ramstetter, and Blomström (2000b, Appendix Table A1) for comparisons with specifications using alternate measures of Japanese affiliate employment or Japanese affiliate value added instead of AERH. 
Appendix Table A2: OLS Regressions Explaining Japanese Exports to a Country by Employment of Japanese and

U.S. Manufacturing Affiliates and Other Variables (Equations (1a, 2a), Small Sample (41-49 countries)

\begin{tabular}{|c|c|c|c|c|c|c|c|c|c|c|c|c|}
\hline \multirow[b]{2}{*}{$\begin{array}{l}\text { Dependent variable, } \\
\text { independent variables, } \\
\text { equation statistics }\end{array}$} & \multicolumn{3}{|c|}{1989 (Equation (1a) } & \multicolumn{3}{|c|}{1989 (Equation $(2 a)$} & \multicolumn{3}{|c|}{1995 (Equation (1a) } & \multicolumn{3}{|c|}{1995 (Equation (2a) } \\
\hline & $\begin{array}{r}\text { Coeffi- } \\
\text { cients, } \\
\text { etc. }\end{array}$ & $\begin{array}{r}\text { Signifi- } \\
\text { cance } \\
\text { level, } \\
\text { OLS }\end{array}$ & $\begin{array}{r}\text { Signifi- } \\
\text { cance } \\
\text { level, } \\
\text { White }\end{array}$ & $\begin{array}{r}\text { Coeffi- } \\
\text { cients, } \\
\text { etc. }\end{array}$ & $\begin{array}{r}\text { Signifi- } \\
\text { cance } \\
\text { level, } \\
\text { OLS }\end{array}$ & $\begin{array}{r}\text { Signifi- } \\
\text { cance } \\
\text { level, } \\
\text { White }\end{array}$ & $\begin{array}{r}\text { Coeffi- } \\
\text { cients, } \\
\text { etc. }\end{array}$ & $\begin{array}{r}\text { Signifi- } \\
\text { cance } \\
\text { level, } \\
\text { OLS }\end{array}$ & $\begin{array}{r}\text { Signifi- } \\
\text { cance } \\
\text { level, } \\
\text { White }\end{array}$ & $\begin{array}{r}\text { Coeffi- } \\
\text { cients, } \\
\text { etc. }\end{array}$ & $\begin{array}{r}\text { Signifi- } \\
\text { cance } \\
\text { level, } \\
\text { OLS } \\
\end{array}$ & $\begin{array}{r}\text { Signifi- } \\
\text { cance } \\
\text { level, } \\
\text { White }\end{array}$ \\
\hline \multicolumn{13}{|c|}{ Food, beverages, tobacco (48 countries for 1989,49 countries for 1995 ) } \\
\hline Constant (thousands) & 12.322 & 0.002 & 0.045 & 12.016 & 0.003 & 0.046 & 9.958 & 0.002 & 0.019 & 10.062 & 0.002 & 0.017 \\
\hline GDPH & -0.014 & 0.397 & 0.279 & -0.010 & 0.585 & 0.422 & -0.015 & 0.184 & 0.083 & -0.010 & 0.384 & 0.190 \\
\hline GDPPH & 2.197 & 0.029 & 0.029 & 2.327 & 0.026 & 0.024 & 2.073 & 0.004 & 0.031 & 2.218 & 0.002 & 0.022 \\
\hline DISTH & -1.593 & 0.000 & 0.027 & -1.561 & 0.000 & 0.028 & -1.424 & 0.000 & 0.010 & -1.399 & 0.000 & 0.009 \\
\hline AERH & 0.564 & 0.458 & 0.231 & 0.649 & 0.407 & 0.219 & 0.588 & 0.081 & 0.057 & 0.561 & 0.093 & 0.056 \\
\hline UEH & - & - & & -0.076 & 0.587 & 0.472 & - & - & & -0.130 & 0.167 & 0.117 \\
\hline F-stati & 6.681 & 0.000 & 0.000 & 5.318 & 0.001 & 0.001 & 11.943 & 0.000 & 0.000 & 10.162 & 0.000 & 0.000 \\
\hline F-White & 2.836 & 0.014 & 0.014 & 2.382 & 0.027 & 0.027 & 5.308 & 0.000 & 0.000 & 3.438 & 0.003 & 0.003 \\
\hline Adjusted R-squared & 0.326 & - & 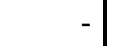 & 0.315 & - & - & 0.477 & - & - & 0.488 & - & - \\
\hline \multicolumn{13}{|c|}{ Chemicals (48 countries for 1989,49 countries for 1995 ) } \\
\hline Constant (thousands) & 51.243 & 0.013 & 0.006 & 42.452 & 0.044 & 0.015 & 82.265 & 0.004 & 0.023 & 81.230 & 0.006 & 0.027 \\
\hline D & 0.109 & 0.244 & 0.072 & 0.215 & 0.068 & 0.002 & -0.051 & 0.555 & 0.543 & -0.041 & 0.697 & 0.657 \\
\hline & 9.444 & 0.066 & 0.015 & 11.760 & 0.028 & 0.001 & 16.413 & 0.007 & 0.005 & 16.824 & 0.010 & 0.004 \\
\hline & -7.501 & 0.000 & 0.001 & -6.756 & 0.002 & 0.001 & -11.698 & 0.000 & 0.006 & -11.600 & 0.000 & 0.007 \\
\hline $\mathrm{AE}$ & 12.515 & 0.000 & 0.024 & 12.956 & 0.000 & 0.021 & 8.939 & 0.000 & 0.014 & 8.891 & 0.000 & 0.016 \\
\hline $\mathrm{EH}$ & & - & & -0.800 & 0.136 & 0.048 & - & - & -1 & -0.132 & 0.850 & 0.825 \\
\hline & 20.036 & 0.000 & 0.000 & 16.980 & 0.000 & 0.000 & 21.637 & 0.000 & 0.000 & 16.938 & 0.000 & 0.000 \\
\hline F-W & 11.152 & 0.000 & 0.000 & 9.323 & 0.000 & 0.000 & 6.997 & 0.000 & 0.000 & 5.241 & 0.000 & 0.000 \\
\hline Adjusted R-sc & 0.618 & & & 0.630 & & & 0.632 & & & 0.624 & & - \\
\hline \multicolumn{13}{|c|}{ Metals (44 countries for 1989,49 countries for 1995 ) } \\
\hline Const: & 144.254 & 0.000 & 0.000 & 118.976 & 0.000 & 0.000 & 99.004 & 0.000 & 0.003 & 86.400 & 0.001 & 0.003 \\
\hline & 0.269 & 0.042 & 0.270 & 0.405 & 0.004 & 0.111 & 0.073 & 0.323 & 0.486 & 0.137 & 0.071 & 0.140 \\
\hline & 760 & 0.452 & 0.446 & 13.621 & 0.089 & 0.035 & 13.876 & 0.012 & 0.008 & 18.371 & 0.001 & 0.000 \\
\hline & -16.758 & 0.000 & 0.000 & -15.461 & 0.000 & 0.000 & -13.752 & 0.000 & 0.000 & -12.923 & 0.000 & 0.000 \\
\hline & 2.440 & 0.208 & 0.315 & 4.523 & 0.028 & 0.024 & 6.157 & 0.000 & 0.001 & 6.499 & 0.000 & 0.000 \\
\hline & - & - & - & -3.527 & 0.018 & 0.016 & - & - & - & -3.116 & 0.018 & 0.028 \\
\hline & 971 & 0.000 & 0.000 & 15.693 & 0.000 & 0.000 & 31.248 & 0.000 & 0.000 & 29.081 & 0.000 & 0.000 \\
\hline & 8.608 & 0.000 & 0.000 & 4.950 & 0.000 & 0.000 & 8.371 & 0.000 & 0.000 & 5.270 & 0.000 & 0.000 \\
\hline Adjusted R & 0.582 & - & $\begin{array}{ll}- & - \\
-1\end{array}$ & 0.631 & - & - & 0.716 & - & - & 0.745 & - & - \\
\hline \multicolumn{13}{|c|}{ Electric machinery ( 47 countries for 1989,49 countries for 1995) } \\
\hline Constan & 29.252 & 0.560 & 0.673 & 30.690 & 0.548 & 0.647 & 167.441 & 0.034 & 0.061 & 167.165 & 0.037 & 0.064 \\
\hline & 0.373 & 0.052 & 0.122 & 0.357 & 0.078 & 0.087 & -0.261 & 0.251 & 0.180 & -0.258 & 0.266 & 0.182 \\
\hline & 557 & 0.000 & 0.000 & 53.979 & 0.000 & 0.000 & 72.759 & 0.000 & 0.002 & 72.938 & 0.000 & 0.002 \\
\hline & -11.329 & 0.028 & 0.137 & -11.442 & 0.028 & 0.129 & -29.503 & 0.000 & 0.011 & -29.473 & 0.000 & 0.012 \\
\hline $\mathrm{AE}$ & 5.530 & 0.000 & 0.001 & 5.429 & 0.000 & 0.001 & 4.255 & 0.000 & 0.000 & 4.290 & 0.000 & 0.000 \\
\hline & - & - & & 0.248 & 0.780 & 0.834 & - & - & - & -0.078 & 0.931 & 0.869 \\
\hline 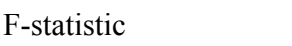 & 961 & 0.000 & 0.000 & 22.677 & 0.000 & 0.000 & 26.645 & 0.000 & 0.000 & 20.837 & 0.000 & 0.000 \\
\hline & 3.309 & 0.006 & 0.006 & 3.269 & 0.004 & 0.004 & 10.521 & 0.000 & 0.000 & 8.150 & 0.000 & 0.000 \\
\hline Adjusted R-squared & 0.709 & _ & & 0.702 & 1 & & 0.681 & & & 0.674 & - & - \\
\hline \multicolumn{13}{|c|}{ ery (41 countries for 1989,49 countries for 1995$)$} \\
\hline Const & 26.603 & 0.598 & 0.627 & 64.543 & 0.181 & 0.157 & 69.532 & 0.264 & 0.348 & 74.375 & 0.249 & 0.314 \\
\hline & & 0.605 & 0.589 & -0.076 & 0.719 & 0.641 & -0.247 & 0.194 & 0.034 & -0.255 & 0.187 & 0.035 \\
\hline $\mathrm{PH}$ & 51.182 & 0.000 & 0.003 & 37.869 & 0.004 & 0.013 & 27.246 & 0.027 & 0.048 & 26.001 & 0.044 & 0.075 \\
\hline & -6.740 & 0.191 & 0.245 & -8.415 & 0.078 & 0.051 & -6.595 & 0.252 & 0.158 & -6.928 & 0.240 & 0.114 \\
\hline AERH & 4.803 & 0.092 & 0.145 & 2.571 & 0.336 & 0.453 & 5.087 & 0.013 & 0.019 & 4.918 & 0.020 & 0.023 \\
\hline & - & - & - & 1.738 & 0.006 & 0.017 & - & - & - & 0.250 & 0.732 & 0.770 \\
\hline & 6.006 & 0.001 & 0.001 & 7.520 & 0.000 & 0.000 & 5.060 & 0.002 & 0.002 & 3.991 & 0.005 & 0.005 \\
\hline & 0.633 & 0.744 & 0.744 & 1.670 & 0.135 & 0.135 & 0.138 & 0.997 & 0.997 & 0.168 & 0.998 & 0.998 \\
\hline Adjusted R-squared & 0.334 & - & - & 0.449 & - & - & 0.253 & - & - & 0.238 & - & - \\
\hline
\end{tabular}

Notes: Industries and terminology are as defined in the notes to Appendix Table A1.

See Lipsey, Ramstetter, and Blomstrom (2000b, Appendix Table A2) for comparisions with specifications using

alternate measures of Japanese affiliate employment or Japanese affiliate value added instead of AERH. 
Appendix Table A3: OLS Regressions Explaining Changes in Japanese Exports to a Country by Initial Employment (Equation (1b) or Changes in Employment (Equation (1c) of Japanese Manufacturing Affiliates and Other Variables, Large Sample (88-93 countries)

\begin{tabular}{|c|c|c|c|c|c|c|c|c|c|}
\hline \multirow[b]{2}{*}{$\begin{array}{l}\text { Dependent variable, } \\
\text { independent variables, } \\
\text { equation statistics }\end{array}$} & \multicolumn{3}{|c|}{ 1986-1989 (93 countries) } & \multicolumn{3}{|c|}{ 1989-1992 (90 countries) } & \multicolumn{3}{|c|}{ 1992-1995 (88 countries) } \\
\hline & $\begin{array}{r}\text { Coeffi- } \\
\text { cients, } \\
\text { etc. }\end{array}$ & $\begin{array}{r}\text { Signifi- } \\
\text { cance } \\
\text { level, } \\
\text { OLS } \\
\end{array}$ & $\begin{array}{r}\text { Signifi- } \\
\text { cance } \\
\text { level, } \\
\text { White }\end{array}$ & $\begin{array}{r}\text { Coeffi- } \\
\text { cients, } \\
\text { etc. }\end{array}$ & $\begin{array}{r}\text { Signifi- } \\
\text { cance } \\
\text { level, } \\
\text { OLS }\end{array}$ & $\begin{array}{r}\text { Signifi- } \\
\text { cance } \\
\text { level, } \\
\text { White }\end{array}$ & $\begin{array}{r}\text { Coeffi- } \\
\text { cients, } \\
\text { etc. }\end{array}$ & $\begin{array}{r}\text { Signifi- } \\
\text { cance } \\
\text { level, } \\
\text { OLS }\end{array}$ & $\begin{array}{r}\text { Signifi- } \\
\text { cance } \\
\text { level, } \\
\text { White }\end{array}$ \\
\hline \multicolumn{10}{|c|}{ Food, beverages, tobacco (Equation (1b) } \\
\hline Constant (thousands) & 0.930 & 0.039 & 0.055 & 0.053 & 0.870 & 0.731 & 0.063 & 0.782 & 0.699 \\
\hline GDPHy2-GDPHy1 & -0.185 & 0.000 & 0.127 & -0.031 & 0.289 & 0.496 & 0.034 & 0.001 & 0.011 \\
\hline JXHy1 & -0.054 & 0.438 & 0.811 & -0.081 & 0.071 & 0.709 & -0.200 & 0.000 & 0.003 \\
\hline gPXJPH & -6.493 & 0.399 & 0.222 & -4.031 & 0.686 & 0.202 & -4.565 & 0.649 & 0.357 \\
\hline AERHy1 & 0.256 & 0.659 & 0.609 & 0.556 & 0.015 & 0.197 & -0.150 & 0.124 & 0.422 \\
\hline F-statistic & 13.851 & 0.000 & 0.000 & 1.735 & 0.150 & 0.150 & 27.000 & 0.000 & 0.000 \\
\hline F-White (Hetero.) & 6.256 & 0.000 & 0.000 & 20.951 & 0.000 & 0.000 & 5.918 & 0.000 & 0.000 \\
\hline Adjusted R-squared & 0.358 & - & - & 0.032 & - & - & 0.544 & - & - \\
\hline \multicolumn{10}{|c|}{ Food, beverages, tobacco (Equation (1c) } \\
\hline Constant (thousands) & 0.943 & 0.033 & 0.037 & 0.110 & 0.735 & 0.352 & 0.073 & 0.747 & 0.658 \\
\hline GDPHy2-GDPHy1 & -0.159 & 0.001 & 0.121 & -0.026 & 0.383 & 0.555 & -0.008 & 0.701 & 0.806 \\
\hline JXHy1 & 0.015 & 0.857 & 0.959 & -0.051 & 0.223 & 0.804 & -0.221 & 0.000 & 0.000 \\
\hline gPXJPH & -7.048 & 0.355 & 0.210 & -2.481 & 0.805 & 0.339 & -1.793 & 0.857 & 0.749 \\
\hline AERHy2-AERHy1 & -0.996 & 0.183 & 0.555 & 0.722 & 0.048 & 0.137 & 0.555 & 0.084 & 0.204 \\
\hline F-statistic & 14.506 & 0.000 & 0.000 & 1.200 & 0.317 & 0.317 & 27.357 & 0.000 & 0.000 \\
\hline F-White (Hetero.) & 7.176 & 0.000 & 0.000 & 24.500 & 0.000 & 0.000 & 5.586 & 0.000 & 0.000 \\
\hline Adjusted R-squared & 0.370 & & & 0.009 & - & - & 0.548 & - & - \\
\hline \multicolumn{10}{|c|}{ Textiles, apparel, leather (Equation (1b) } \\
\hline Constant (thousands) & 0.455 & 0.473 & 0.374 & -0.623 & 0.536 & 0.479 & -2.007 & 0.071 & 0.033 \\
\hline GDPHy2-GDPHy1 & -0.254 & 0.000 & 0.100 & 0.076 & 0.400 & 0.834 & 0.470 & 0.000 & 0.039 \\
\hline JXHy 1 & -0.192 & 0.000 & 0.000 & 0.105 & 0.027 & 0.234 & -0.430 & 0.000 & 0.000 \\
\hline gPXJPH & -9.554 & 0.370 & 0.167 & 11.353 & 0.965 & 0.930 & 110.440 & 0.829 & 0.643 \\
\hline AERHy1 & 0.633 & 0.000 & 0.007 & 0.503 & 0.017 & 0.059 & 0.490 & 0.006 & 0.279 \\
\hline F-statistic & 64.289 & 0.000 & 0.000 & 7.813 & 0.000 & 0.000 & 38.085 & 0.000 & 0.000 \\
\hline F-White (Het & 26.819 & 0.000 & 0.000 & 34.459 & 0.000 & 0.000 & 82.130 & 0.000 & 0.000 \\
\hline Adjusted R-squared & 0.733 & & & 0.234 & - & - & 0.630 & - & - \\
\hline \multicolumn{10}{|c|}{ Textiles, apparel, leather (Equation (1c) } \\
\hline Constant (thousands) & 1.188 & 0.092 & 0.080 & 0.244 & 0.674 & 0.630 & 0.580 & 0.312 & 0.192 \\
\hline GDPHy2-GDPHy1 & -0.316 & 0.000 & 0.106 & -0.302 & 0.000 & 0.037 & 0.129 & 0.001 & 0.203 \\
\hline JXHy1 & -0.144 & 0.000 & 0.016 & 0.156 & 0.000 & 0.000 & -0.462 & 0.000 & 0.000 \\
\hline gPXJPH & -15.698 & 0.194 & 0.096 & -8.478 & 0.634 & 0.265 & -24.816 & 0.315 & 0.093 \\
\hline AERHy2-AERHy1 & 0.366 & 0.439 & 0.808 & 2.693 & 0.000 & 0.000 & 2.314 & 0.000 & 0.000 \\
\hline F-statistic & 45.119 & 0.000 & 0.000 & 64.210 & 0.000 & 0.000 & 202.154 & 0.000 & 0.000 \\
\hline F-White (Hetero.) & 46.655 & 0.000 & 0.000 & 16.612 & 0.000 & 0.000 & 32.575 & 0.000 & 0.000 \\
\hline Adjusted R-squared & 0.657 & - & - & 0.740 & - & - & 0.902 & - & - \\
\hline \multicolumn{10}{|c|}{ Wood, furniture, paper (Equation (1b) } \\
\hline Constant (thousands) & 0.029 & 0.944 & 0.916 & 0.350 & 0.325 & 0.325 & 0.094 & 0.591 & 0.482 \\
\hline GDPHy2-GDPHy1 & 0.033 & 0.396 & 0.655 & -0.005 & 0.885 & 0.967 & -0.021 & 0.005 & 0.040 \\
\hline JXHy1 & 0.046 & 0.516 & 0.819 & 0.152 & 0.001 & 0.334 & -0.232 & 0.000 & 0.000 \\
\hline gPXJPH & -6.145 & 0.375 & 0.232 & -1.182 & 0.913 & 0.763 & -1.464 & 0.848 & 0.763 \\
\hline AERHy1 & 0.643 & 0.304 & 0.129 & -0.367 & 0.309 & 0.505 & 0.750 & 0.000 & 0.017 \\
\hline F-statistic & 2.065 & 0.092 & 0.092 & 4.149 & 0.004 & 0.004 & 91.341 & 0.000 & 0.000 \\
\hline F-White (Hetero.) & 10.840 & 0.000 & 0.000 & 82.989 & 0.000 & 0.000 & 5.578 & 0.000 & 0.000 \\
\hline Adjusted R-squared & 0.044 & - & - & 0.124 & - & - & 0.806 & - & - \\
\hline
\end{tabular}


Appendix Table A3 (continued, 2/4)

\begin{tabular}{|c|c|c|c|c|c|c|c|c|c|}
\hline \multirow[b]{2}{*}{$\begin{array}{l}\text { Dependent variable, } \\
\text { independent variables, } \\
\text { equation statistics }\end{array}$} & \multicolumn{3}{|c|}{ 1986-1989 (93 countries) } & \multicolumn{3}{|c|}{ 1989-1992 (90 countries) } & \multicolumn{3}{|c|}{ 1992-1995 (88 countries) } \\
\hline & $\begin{array}{r}\text { Coeffi- } \\
\text { cients, etc. }\end{array}$ & $\begin{array}{r}\text { Signifi- } \\
\text { cance } \\
\text { level, OLS }\end{array}$ & $\begin{array}{r}\text { Signifi- } \\
\text { cance } \\
\text { level, } \\
\text { White }\end{array}$ & $\begin{array}{l}\text { Coeffi- } \\
\text { cients, etc. }\end{array}$ & $\begin{array}{r}\text { Signifi- } \\
\text { cance } \\
\text { level, OLS }\end{array}$ & $\begin{array}{r}\text { Signifi- } \\
\text { cance } \\
\text { level, } \\
\text { White }\end{array}$ & $\begin{array}{r}\text { Coeffi- } \\
\text { cients, etc. }\end{array}$ & $\begin{array}{r}\text { Signifi- } \\
\text { cance } \\
\text { level, OLS }\end{array}$ & $\begin{array}{r}\text { Signifi- } \\
\text { cance } \\
\text { level, } \\
\text { White }\end{array}$ \\
\hline \multicolumn{10}{|c|}{ Wood, furniture, paper (Equation (1c) } \\
\hline Constant (thousands) & 0.170 & 0.648 & 0.537 & 0.314 & 0.366 & 0.358 & 0.246 & 0.208 & 0.096 \\
\hline GDPHy2-GDPHy1 & -0.051 & 0.236 & 0.502 & -0.020 & 0.528 & 0.864 & -0.012 & 0.229 & 0.477 \\
\hline JXHy1 & 0.041 & 0.542 & 0.835 & 0.149 & 0.001 & 0.352 & -0.212 & 0.000 & 0.000 \\
\hline gPXJPH & -6.399 & 0.319 & 0.180 & -1.587 & 0.882 & 0.674 & -5.313 & 0.537 & 0.220 \\
\hline AERHy2-AERHy1 & 3.567 & 0.000 & 0.113 & 1.719 & 0.067 & 0.002 & -0.157 & 0.739 & 0.802 \\
\hline F-statistic & 5.795 & 0.000 & 0.000 & 4.854 & 0.001 & 0.001 & 67.231 & 0.000 & 0.000 \\
\hline F-White (Hetero.) & 15.507 & 0.000 & 0.000 & 72.483 & 0.000 & 0.000 & 6.840 & 0.000 & 0.000 \\
\hline Adjusted R-squared & 0.173 & - & - & 0.148 & - & - & 0.753 & & - \\
\hline \multicolumn{10}{|c|}{ Chemicals (Equation (1b) } \\
\hline Constant (thousands) & 0.369 & 0.651 & 0.395 & 0.474 & 0.606 & 0.359 & 1.070 & 0.303 & 0.219 \\
\hline GDPHy2-GDPHy1 & -0.663 & 0.000 & 0.000 & 0.115 & 0.247 & 0.395 & 0.025 & 0.597 & 0.681 \\
\hline JXHy 1 & 0.286 & 0.000 & 0.000 & 0.129 & 0.000 & 0.184 & 0.159 & 0.000 & 0.000 \\
\hline gPXJPH & -19.229 & 0.170 & 0.030 & -31.055 & 0.273 & 0.080 & -84.896 & 0.065 & 0.021 \\
\hline AERHy1 & 3.531 & 0.000 & 0.110 & 0.245 & 0.545 & 0.749 & -0.155 & 0.619 & 0.839 \\
\hline F-statistic & 71.314 & 0.000 & 0.000 & 34.029 & 0.000 & 0.000 & 45.704 & 0.000 & 0.000 \\
\hline F-White (Hetero.) & 11.805 & 0.000 & 0.000 & 16.424 & 0.000 & 0.000 & 22.781 & 0.000 & 0.000 \\
\hline Adjusted R-squared & 0.754 & - & - & 0.597 & - & - & 0.673 & - & - \\
\hline \multicolumn{10}{|c|}{ Chemicals (Equation (1c) } \\
\hline Constant (thousands) & 1.187 & 0.202 & 0.172 & 0.382 & 0.673 & 0.456 & 0.509 & 0.576 & 0.434 \\
\hline GDPHy2-GDPHy1 & -0.661 & 0.000 & 0.075 & 0.062 & 0.527 & 0.737 & -0.117 & 0.015 & 0.098 \\
\hline JXHy1 & 0.344 & 0.000 & 0.000 & 0.125 & 0.000 & 0.110 & 0.158 & 0.000 & 0.000 \\
\hline gPXJPH & -25.252 & 0.109 & 0.073 & -29.782 & 0.285 & 0.070 & -66.725 & 0.097 & 0.044 \\
\hline AERHy2-AERHy1 & 0.757 & 0.215 & 0.696 & 2.038 & 0.089 & 0.299 & 3.657 & 0.000 & 0.000 \\
\hline F-statistic & 51.916 & 0.000 & 0.000 & 35.709 & 0.000 & 0.000 & 66.268 & 0.000 & 0.000 \\
\hline F-White (Hetero.) & 57.351 & 0.000 & 0.000 & 16.320 & 0.000 & 0.000 & 11.725 & 0.000 & 0.000 \\
\hline Adjusted R-squared & 0.689 & - & - & 0.609 & - & - & 0.750 & & - \\
\hline \multicolumn{10}{|l|}{ Metals (Equation (1b) } \\
\hline Constant (thousands) & 2.698 & 0.410 & 0.244 & 3.900 & 0.020 & 0.002 & 4.084 & 0.118 & 0.163 \\
\hline GDPHy2-GDPHy1 & -0.037 & 0.928 & 0.962 & -1.115 & 0.000 & 0.002 & 0.139 & 0.253 & 0.607 \\
\hline JXHy1 & -0.219 & 0.000 & 0.213 & -0.088 & 0.006 & 0.137 & 0.010 & 0.823 & 0.888 \\
\hline gPXJPH & -49.775 & 0.380 & 0.237 & -80.984 & 0.112 & 0.011 & -187.029 & 0.104 & 0.026 \\
\hline AERHy1 & 2.696 & 0.002 & 0.210 & 1.142 & 0.010 & 0.237 & -1.487 & 0.019 & 0.256 \\
\hline F-statistic & 11.460 & 0.000 & 0.000 & 38.509 & 0.000 & 0.000 & 2.830 & 0.030 & 0.030 \\
\hline F-White (Hetero.) & 16.505 & 0.000 & 0.000 & 14.053 & 0.000 & 0.000 & 38.863 & 0.000 & 0.000 \\
\hline Adjusted R-squared & 0.313 & - & - & 0.628 & - & - & 0.078 & - & - \\
\hline \multicolumn{10}{|l|}{ Metals (Equation (1c) } \\
\hline Constant (thousands) & 4.539 & 0.140 & 0.080 & 4.322 & 0.010 & 0.001 & 2.809 & 0.255 & 0.206 \\
\hline GDPHy2-GDPHy1 & 0.324 & 0.371 & 0.687 & -1.067 & 0.000 & 0.012 & -0.077 & 0.550 & 0.768 \\
\hline JXHy1 & -0.277 & 0.000 & 0.125 & -0.087 & 0.007 & 0.123 & -0.097 & 0.005 & 0.424 \\
\hline gPXJPH & -76.877 & 0.150 & 0.179 & -81.932 & 0.109 & 0.015 & -99.498 & 0.363 & 0.141 \\
\hline AERHy2-AERHy1 & 12.153 & 0.000 & 0.029 & 4.026 & 0.012 & 0.313 & 6.223 & 0.000 & 0.109 \\
\hline F-statistic & 15.658 & 0.000 & 0.000 & 38.195 & 0.000 & 0.000 & 5.076 & 0.001 & 0.001 \\
\hline F-White (Hetero.) & 27.729 & 0.000 & 0.000 & 22.773 & 0.000 & 0.000 & 17.614 & 0.000 & 0.000 \\
\hline Adjusted R-squared & 0.389 & - & - & 0.626 & - & - & 0.158 & & \\
\hline
\end{tabular}


Appendix Table A3 (continued, 3/4)

\begin{tabular}{|c|c|c|c|c|c|c|c|c|c|}
\hline \multirow[b]{2}{*}{$\begin{array}{l}\text { Dependent variable, } \\
\text { independent variables, } \\
\text { equation statistics }\end{array}$} & \multicolumn{3}{|c|}{ 1986-1989 (93 countries) } & \multicolumn{3}{|c|}{ 1989-1992 (90 countries) } & \multicolumn{3}{|c|}{ 1992-1995 (88 countries) } \\
\hline & $\begin{array}{r}\text { Coeffi- } \\
\text { cients, etc. }\end{array}$ & $\begin{array}{r}\text { Signifi- } \\
\text { cance } \\
\text { level, OLS } \\
\end{array}$ & $\begin{array}{r}\text { Signifi- } \\
\text { cance } \\
\text { level, } \\
\text { White }\end{array}$ & $\begin{array}{r}\text { Coeffi- } \\
\text { cients, etc. }\end{array}$ & $\begin{array}{r}\text { Signifi- } \\
\text { cance } \\
\text { level, OLS }\end{array}$ & $\begin{array}{r}\text { Signifi- } \\
\text { cance } \\
\text { level, } \\
\text { White }\end{array}$ & $\begin{array}{r}\text { Coeffi- } \\
\text { cients, etc. }\end{array}$ & $\begin{array}{r}\text { Signifi- } \\
\text { cance } \\
\text { level, OLS }\end{array}$ & $\begin{array}{r}\text { Signifi- } \\
\text { cance } \\
\text { level, } \\
\text { White } \\
\end{array}$ \\
\hline \multicolumn{10}{|c|}{ All machinery (general, electric, tranportation, and precision) combined (Equation (1b) } \\
\hline Constant (thousands) & 17.478 & 0.123 & 0.025 & 26.173 & 0.063 & 0.022 & -9.223 & 0.483 & 0.371 \\
\hline GDPHy2-GDPHy1 & -0.894 & 0.536 & 0.754 & 1.377 & 0.327 & 0.428 & 1.220 & 0.038 & 0.026 \\
\hline JXHy1 & -0.126 & 0.000 & 0.000 & -0.133 & 0.000 & 0.000 & -0.169 & 0.000 & 0.000 \\
\hline gPXJPH & -192.035 & 0.310 & 0.141 & -711.082 & 0.095 & 0.039 & -1062.416 & 0.066 & 0.076 \\
\hline AERHy1 & 6.486 & 0.000 & 0.000 & 3.933 & 0.000 & 0.000 & 4.287 & 0.000 & 0.000 \\
\hline F-statistic & 51.842 & 0.000 & 0.000 & 15.692 & 0.000 & 0.000 & 36.498 & 0.000 & 0.000 \\
\hline F-White (Hetero.) & 8.500 & 0.000 & 0.000 & 2.372 & 0.024 & 0.024 & 7.981 & 0.000 & 0.000 \\
\hline Adjusted R-squared & 0.689 & & & 0.398 & - & - & 0.620 & & - \\
\hline \multicolumn{10}{|c|}{ All machinery (general, electric, tranportation, and precision) combined (Equation (1c) } \\
\hline Constant (thousands) & 29.866 & 0.023 & 0.010 & 36.420 & 0.015 & 0.004 & 8.455 & 0.571 & 0.566 \\
\hline GDPHy2-GDPHy1 & -1.805 & 0.306 & 0.600 & 1.337 & 0.388 & 0.373 & -1.505 & 0.131 & 0.293 \\
\hline JXHy1 & -0.134 & 0.000 & 0.000 & -0.077 & 0.000 & 0.000 & -0.078 & 0.000 & 0.000 \\
\hline gPXJPH & -355.662 & 0.107 & 0.136 & -661.258 & 0.147 & 0.023 & -1297.521 & 0.054 & 0.032 \\
\hline AERHy2-AERHy1 & 9.522 & 0.000 & 0.000 & 4.719 & 0.001 & 0.009 & 6.537 & 0.000 & 0.003 \\
\hline F-statistic & 31.784 & 0.000 & 0.000 & 10.869 & 0.000 & 0.000 & 21.563 & 0.000 & 0.000 \\
\hline F-White (Hetero.) & 15.672 & 0.000 & 0.000 & 4.611 & 0.000 & 0.000 & 7.630 & 0.000 & 0.000 \\
\hline Adjusted R-squared & 0.572 & - & - & 0.307 & - & - & 0.486 & - & - \\
\hline \multicolumn{10}{|c|}{ General \& precision machinery (Equation (1b) } \\
\hline Constant (thousands) & 6.174 & 0.217 & 0.054 & 6.243 & 0.195 & 0.024 & -0.144 & 0.979 & 0.975 \\
\hline GDPHy2-GDPHy1 & -2.237 & 0.003 & 0.249 & 1.485 & 0.003 & 0.024 & 1.164 & 0.000 & 0.000 \\
\hline JXHy1 & 0.188 & 0.000 & 0.053 & -0.200 & 0.000 & 0.009 & -0.173 & 0.000 & 0.000 \\
\hline gPXJPH & -81.730 & 0.337 & 0.120 & -230.928 & 0.115 & 0.070 & -313.349 & 0.198 & 0.110 \\
\hline AERHy1 & 10.553 & 0.000 & 0.158 & 12.673 & 0.000 & 0.089 & 9.595 & 0.000 & 0.000 \\
\hline F-statistic & 67.190 & 0.000 & 0.000 & 15.682 & 0.000 & 0.000 & 18.276 & 0.000 & 0.000 \\
\hline F-White (H & 9.085 & 0.000 & 0.000 & 7.229 & 0.000 & 0.000 & 4.587 & 0.000 & 0.000 \\
\hline Adjusted R-squared & 0.742 & - & - & 0.398 & - & - & 0.443 & - & - \\
\hline \multicolumn{10}{|c|}{ General \& precision machinery (Equation (1c) } \\
\hline Constant (thousands) & 3.421 & 0.442 & 0.367 & 11.533 & 0.038 & 0.014 & 3.031 & 0.617 & 0.521 \\
\hline GDPHy2-GDPHy1 & -3.042 & 0.000 & 0.217 & 0.935 & 0.126 & 0.120 & 0.988 & 0.004 & 0.024 \\
\hline JXHy1 & 0.247 & 0.000 & 0.005 & -0.072 & 0.000 & 0.012 & -0.046 & 0.003 & 0.053 \\
\hline gPXJPH & -81.246 & 0.280 & 0.195 & -223.143 & 0.189 & 0.043 & -515.046 & 0.057 & 0.016 \\
\hline AERHy2-AERHy1 & 26.639 & 0.000 & 0.000 & 7.807 & 0.016 & 0.011 & 6.512 & 0.031 & 0.268 \\
\hline F-statistic & 91.672 & 0.000 & 0.000 & 6.132 & 0.000 & 0.000 & 10.317 & 0.000 & 0.000 \\
\hline F-White (Het & 47.985 & 0.000 & 0.000 & 3.771 & 0.001 & 0.001 & 10.994 & 0.000 & 0.000 \\
\hline Adjusted R-squared & 0.798 & - & - & 0.187 & - & - & 0.300 & - & - \\
\hline \multicolumn{10}{|c|}{ Electric machinery (Equation (1b) } \\
\hline Constant (thousands) & 4.974 & 0.190 & 0.129 & 5.609 & 0.296 & 0.217 & -3.850 & 0.528 & 0.433 \\
\hline GDPHy2-GDPHy1 & 0.174 & 0.715 & 0.794 & -0.928 & 0.083 & 0.211 & 0.302 & 0.249 & 0.542 \\
\hline JXHy1 & -0.167 & 0.000 & 0.000 & -0.078 & 0.004 & 0.095 & -0.092 & 0.000 & 0.005 \\
\hline gPXJPH & -41.370 & 0.516 & 0.245 & -173.927 & 0.287 & 0.070 & -259.703 & 0.332 & 0.294 \\
\hline AERHy1 & 4.036 & 0.000 & 0.000 & 2.606 & 0.000 & 0.000 & 2.923 & 0.000 & 0.000 \\
\hline F-statistic & 52.543 & 0.000 & 0.000 & 8.838 & 0.000 & 0.000 & 19.815 & 0.000 & 0.000 \\
\hline F-White $(\mathrm{H}$ & 20.411 & 0.000 & 0.000 & 5.646 & 0.000 & 0.000 & 4.312 & 0.000 & 0.000 \\
\hline Adjusted R-squared & 0.691 & - & - & 0.261 & - & - & 0.464 & - & - \\
\hline
\end{tabular}


Appendix Table A3 (continued, 4/4)

\begin{tabular}{|c|c|c|c|c|c|c|c|c|c|}
\hline \multirow[b]{2}{*}{$\begin{array}{l}\text { Dependent variable, } \\
\text { independent variables, } \\
\text { equation statistics }\end{array}$} & \multicolumn{3}{|c|}{ 1986-1989 (93 countries) } & \multicolumn{3}{|c|}{ 1989-1992 (90 countries) } & \multicolumn{3}{|c|}{ 1992-1995 (88 countries) } \\
\hline & $\begin{array}{r}\text { Coeffi- } \\
\text { cients, etc. }\end{array}$ & $\begin{array}{r}\text { Signifi- } \\
\text { cance } \\
\text { level, OLS }\end{array}$ & $\begin{array}{r}\text { Signifi- } \\
\text { cance } \\
\text { level, } \\
\text { White }\end{array}$ & $\begin{array}{l}\text { Coeffi- } \\
\text { cients, etc. }\end{array}$ & $\begin{array}{r}\text { Signifi- } \\
\text { cance } \\
\text { level, OLS }\end{array}$ & $\begin{array}{r}\text { Signifi- } \\
\text { cance } \\
\text { level, } \\
\text { White }\end{array}$ & $\begin{array}{r}\text { Coeffi- } \\
\text { cients, etc. }\end{array}$ & $\begin{array}{r}\text { Signifi- } \\
\text { cance } \\
\text { level, OLS }\end{array}$ & $\begin{array}{r}\text { Signifi- } \\
\text { cance } \\
\text { level, } \\
\text { White }\end{array}$ \\
\hline \multicolumn{10}{|c|}{ Electric machinery (Equation (1c) } \\
\hline Constant (thousands) & 12.353 & 0.023 & 0.034 & 8.593 & 0.131 & 0.046 & 2.220 & 0.726 & 0.707 \\
\hline GDPHy2-GDPHy1 & -0.349 & 0.618 & 0.694 & -1.153 & 0.048 & 0.191 & -1.085 & 0.004 & 0.091 \\
\hline JXHy1 & -0.116 & 0.000 & 0.018 & 0.015 & 0.506 & 0.760 & 0.039 & 0.041 & 0.365 \\
\hline gPXJPH & -119.811 & 0.191 & 0.160 & -143.990 & 0.410 & 0.042 & -348.189 & 0.219 & 0.154 \\
\hline AERHy2-AERHy1 & 2.907 & 0.002 & 0.005 & 3.102 & 0.000 & 0.084 & 4.956 & 0.000 & 0.000 \\
\hline F-statistic & 13.778 & 0.000 & 0.000 & 5.164 & 0.001 & 0.001 & 15.439 & 0.000 & 0.000 \\
\hline F-White (Hetero.) & 21.219 & 0.000 & 0.000 & 17.324 & 0.000 & 0.000 & 6.069 & 0.000 & 0.000 \\
\hline Adjusted R-squared & 0.357 & - & - & 0.158 & - & - & 0.399 & & - \\
\hline \multicolumn{10}{|c|}{ Transportation machinery (Equation (1b) } \\
\hline Constant (thousands) & 8.923 & 0.060 & 0.010 & 17.393 & 0.002 & 0.002 & -2.840 & 0.658 & 0.613 \\
\hline GDPHy2-GDPHy1 & -0.372 & 0.528 & 0.743 & 1.314 & 0.020 & 0.002 & -0.331 & 0.247 & 0.100 \\
\hline JXHy1 & -0.237 & 0.000 & 0.000 & -0.111 & 0.000 & 0.000 & -0.191 & 0.000 & 0.000 \\
\hline gPXJPH & -85.386 & 0.274 & 0.120 & -308.018 & 0.064 & 0.013 & -445.747 & 0.115 & 0.100 \\
\hline AERHy1 & 5.643 & 0.000 & 0.034 & 0.152 & 0.890 & 0.906 & 2.434 & 0.005 & 0.177 \\
\hline F-statistic & 327.002 & 0.000 & 0.000 & 22.309 & 0.000 & 0.000 & 53.043 & 0.000 & 0.000 \\
\hline F-White (Hetero.) & 13.451 & 0.000 & 0.000 & 2.276 & 0.030 & 0.030 & 9.698 & 0.000 & 0.000 \\
\hline Adjusted R-squared & 0.934 & - & - & 0.489 & - & - & 0.705 & - & - \\
\hline \multicolumn{10}{|c|}{ Transportation machinery (Equation (1c) } \\
\hline Constant (thousands) & 11.777 & 0.009 & 0.002 & 17.147 & 0.002 & 0.001 & -0.536 & 0.930 & 0.910 \\
\hline GDPHy2-GDPHy1 & -1.093 & 0.086 & 0.298 & 1.028 & 0.068 & 0.030 & -1.458 & 0.002 & 0.020 \\
\hline JXHy1 & -0.285 & 0.000 & 0.000 & -0.114 & 0.000 & 0.000 & -0.175 & 0.000 & 0.000 \\
\hline gPXJPH & -98.150 & 0.193 & 0.095 & -292.977 & 0.076 & 0.011 & -341.749 & 0.215 & 0.156 \\
\hline AERHy2-AERHy1 & 12.105 & 0.000 & 0.003 & 2.774 & 0.199 & 0.118 & 8.593 & 0.000 & 0.020 \\
\hline F-statistic & 348.365 & 0.000 & 0.000 & 23.159 & 0.000 & 0.000 & 57.660 & 0.000 & 0.000 \\
\hline F-White (Hetero.) & 11.980 & 0.000 & 0.000 & 1.436 & 0.194 & 0.194 & 9.365 & 0.000 & 0.000 \\
\hline Adjusted R-squared & 0.938 & - & - & 0.499 & - & - & 0.723 & & - \\
\hline \multicolumn{10}{|c|}{ Other manufacturing (Equation (1b) } \\
\hline Constant (thousands) & 0.632 & 0.393 & 0.284 & 2.698 & 0.029 & 0.007 & 0.665 & 0.503 & 0.410 \\
\hline GDPHy2-GDPHy1 & -0.005 & 0.952 & 0.966 & 0.204 & 0.108 & 0.057 & 0.151 & 0.001 & 0.006 \\
\hline JXHy1 & -0.066 & 0.004 & 0.046 & 0.004 & 0.953 & 0.982 & -0.170 & 0.000 & 0.012 \\
\hline gPXJPH & -8.564 & 0.489 & 0.174 & -55.216 & 0.142 & 0.020 & -81.368 & 0.068 & 0.018 \\
\hline AERHy1 & 2.281 & 0.000 & 0.069 & -0.645 & 0.173 & 0.593 & 0.555 & 0.022 & 0.249 \\
\hline F-statistic & 10.159 & 0.000 & 0.000 & 3.563 & 0.010 & 0.010 & 14.250 & 0.000 & 0.000 \\
\hline F-White (Het & 11.574 & 0.000 & 0.000 & 17.321 & 0.000 & 0.000 & 13.909 & 0.000 & 0.000 \\
\hline Adjusted R-squared & 0.285 & - & - & 0.103 & - & - & 0.379 & - & - \\
\hline \multicolumn{10}{|c|}{ Other manufacturing (Equation (1c) } \\
\hline Constant (thousands) & 0.973 & 0.243 & 0.218 & 1.600 & 0.120 & 0.015 & 0.337 & 0.734 & 0.635 \\
\hline GDPHy2-GDPHy1 & 0.127 & 0.214 & 0.069 & -0.115 & 0.291 & 0.395 & 0.068 & 0.261 & 0.413 \\
\hline JXHy1 & 0.096 & 0.032 & 0.413 & 0.005 & 0.836 & 0.917 & -0.093 & 0.000 & 0.000 \\
\hline gPXJPH & -9.911 & 0.473 & 0.190 & -39.926 & 0.200 & 0.016 & -84.621 & 0.056 & 0.020 \\
\hline AERHy2-AERHy1 & -1.268 & 0.001 & 0.187 & 4.150 & 0.000 & 0.000 & 1.101 & 0.012 & 0.166 \\
\hline F-statistic & 3.924 & 0.006 & 0.006 & 14.895 & 0.000 & 0.000 & 14.719 & 0.000 & 0.000 \\
\hline F-White (Hetero.) & 2.994 & 0.005 & 0.005 & 13.109 & 0.000 & 0.000 & 11.090 & 0.000 & 0.000 \\
\hline Adjusted R-squared & 0.113 & - & - & 0.384 & - & - & 0.387 & & \\
\hline
\end{tabular}

Notes: Industries and terminology are as defined in the notes to Appendix Table A1. 
Appendix Table A4: OLS Regressions Explaining Changes in Japanese Exports to a Country by Initial Employment (Equation (1b, 2b) or Changes in Employment (Equations (1c, 2c) of Japanese and U.S. Manufacturing Affiliates and Other Variables, 1989-1995, Small Sample (41-48 countries)

\begin{tabular}{|c|c|c|c|c|c|c|c|c|c|c|c|c|}
\hline \multirow[b]{3}{*}{$\begin{array}{l}\text { Dependent variable, independent } \\
\text { variables, equation statistics }\end{array}$} & \multicolumn{6}{|c|}{$\begin{array}{l}\text { Equations with Initial Employment } \\
\text { (AERHy1 \& UEHy1) }\end{array}$} & \multicolumn{6}{|c|}{$\begin{array}{l}\text { Equations with Changes in Employment } \\
\text { (AERHy2-AERHy1 \& UEHy2-UEHy1) }\end{array}$} \\
\hline & \multicolumn{3}{|c|}{ Equation (1b) } & \multicolumn{3}{|c|}{ Equation (2b) } & \multicolumn{3}{|c|}{ Equation (1c) } & \multicolumn{3}{|c|}{ Equation $(2 \mathrm{c})$} \\
\hline & $\begin{array}{r}\text { Coeffi- } \\
\text { cients, etc. }\end{array}$ & $\begin{array}{r}\text { Signit1- } \\
\text { cance } \\
\text { level, } \\
\text { OLS }\end{array}$ & $\begin{array}{r}\text { S1gniti- } \\
\text { cance } \\
\text { level, } \\
\text { White }\end{array}$ & $\begin{array}{r}\text { Coeffi- } \\
\text { cients, etc. }\end{array}$ & \begin{tabular}{|r|} 
Signit1- \\
cance \\
level, \\
OLS
\end{tabular} & $\begin{array}{r}\text { Signit1- } \\
\text { cance } \\
\text { level, } \\
\text { White }\end{array}$ & $\begin{array}{r}\text { Coeffi- } \\
\text { cients, } \\
\text { etc. }\end{array}$ & \begin{tabular}{|r|} 
Signit1- \\
cance \\
level, \\
OLS
\end{tabular} & $\begin{array}{r}\text { Signifi- } \\
\text { cance } \\
\text { level, } \\
\text { White }\end{array}$ & $\begin{array}{l}\text { Coeffi- } \\
\text { cients, etc. }\end{array}$ & $\begin{array}{r}\text { Signit1- } \\
\text { cance } \\
\text { level, } \\
\text { OLS }\end{array}$ & $\begin{array}{r}\text { Signit1- } \\
\text { cance } \\
\text { level, } \\
\text { White }\end{array}$ \\
\hline \multicolumn{13}{|c|}{ Food, beverages, tobacco ( 48 countries) } \\
\hline Constant (thousands) & -0.690 & 0.257 & 0.004 & 0.014 & 0.983 & 0.956 & -0.238 & 0.715 & 0.370 & -0.195 & 0.772 & 0.516 \\
\hline GDPHy2-GDPHy1 & 0.027 & 0.054 & 0.000 & 0.025 & 0.059 & 0.000 & 0.009 & 0.745 & 0.725 & 0.009 & 0.739 & 0.716 \\
\hline JXHy1 & -0.218 & 0.000 & 0.090 & -0.230 & 0.000 & 0.071 & -0.192 & 0.001 & 0.137 & -0.193 & 0.001 & 0.137 \\
\hline gPXJPH & -19.114 & 0.496 & 0.230 & -15.258 & 0.566 & 0.296 & -16.088 & 0.598 & 0.354 & -16.800 & 0.588 & 0.355 \\
\hline AERHy1 or AERHy2-AERHy1 & 0.742 & 0.020 & 0.246 & 0.902 & 0.004 & 0.173 & 0.412 & 0.259 & 0.207 & 0.417 & 0.259 & 0.183 \\
\hline UEHy1 or UEHy2-UEHy1 & - & & & -0.122 & 0.018 & 0.035 & - & - & & -0.049 & 0.752 & 0.581 \\
\hline F-statistic & 5.883 & 0.001 & 0.001 & 6.489 & 0.000 & 0.000 & 4.330 & 0.005 & 0.005 & 3.410 & 0.011 & 0.011 \\
\hline F-White (Heteroscedasticity) & 6.611 & 0.000 & 0.000 & 7.376 & 0.000 & 0.000 & 2.809 & 0.015 & 0.015 & 2.205 & 0.040 & 0.040 \\
\hline Adjusted R-squared & 0.298 & - & - & 0.374 & - & - & 0.225 & - & - & 0.208 & - & - \\
\hline \multicolumn{13}{|l|}{ Chemicals (48 countries) } \\
\hline Constant (thousands) & -1.274 & 0.717 & 0.539 & 1.129 & 0.769 & 0.593 & -0.063 & 0.985 & 0.975 & -0.051 & 0.988 & 0.980 \\
\hline GDPHy2-GDPHy1 & 0.108 & 0.208 & 0.097 & 0.114 & 0.179 & 0.061 & -0.057 & 0.660 & 0.557 & -0.084 & 0.541 & 0.391 \\
\hline JXHy1 & 0.253 & 0.000 & 0.104 & 0.245 & 0.000 & 0.116 & 0.300 & 0.000 & 0.020 & 0.298 & 0.000 & 0.022 \\
\hline gPXJPH & -197.206 & 0.245 & 0.173 & -174.314 & 0.299 & 0.196 & -204.413 & 0.227 & 0.087 & -200.217 & 0.240 & 0.084 \\
\hline AERHy1 or AERHy2-AERHy1 & 2.590 & 0.103 & 0.267 & 2.799 & 0.077 & 0.213 & 2.954 & 0.100 & 0.078 & 3.107 & 0.089 & 0.061 \\
\hline UEHy1 or UEHy2-UEHy1 & - & & - & -0.279 & 0.151 & 0.007 & - & - & - & 0.537 & 0.490 & 0.281 \\
\hline F-statistic & 17.514 & 0.000 & 0.000 & 14.824 & 0.000 & 0.000 & 17.550 & 0.000 & 0.000 & 13.965 & 0.000 & 0.000 \\
\hline F-White (Heteroscedasticity) & 3.393 & 0.005 & 0.005 & 2.926 & 0.009 & 0.009 & 3.923 & 0.002 & 0.002 & 3.016 & 0.007 & 0.007 \\
\hline Adjusted R-squared & 0.589 & - & - & 0.600 & - & - & 0.590 & - & - & 0.585 & - & - \\
\hline \multicolumn{13}{|l|}{ Metals (43 countries) } \\
\hline Constant (thousands) & -0.372 & 0.913 & 0.833 & 0.894 & 0.805 & 0.615 & 2.761 & 0.391 & 0.241 & 2.308 & 0.483 & 0.330 \\
\hline GDPHy2-GDPHy1 & -0.362 & 0.000 & 0.004 & -0.356 & 0.000 & 0.005 & -0.461 & 0.000 & 0.002 & -0.464 & 0.000 & 0.002 \\
\hline JXHy1 & 0.084 & 0.049 & 0.271 & 0.074 & 0.088 & 0.325 & 0.067 & 0.105 & 0.319 & 0.065 & 0.120 & 0.347 \\
\hline gPXJPH & -159.584 & 0.332 & 0.162 & -126.806 & 0.448 & 0.266 & -153.173 & 0.331 & 0.238 & -161.811 & 0.309 & 0.228 \\
\hline AERHy1 or AERHy2-AERHy1 & 1.194 & 0.045 & 0.217 & 1.468 & 0.026 & 0.133 & 2.900 & 0.007 & 0.142 & 3.171 & 0.006 & 0.126 \\
\hline UEHy1 or UEHy2-UEHy1 & & & & -0.417 & 0.301 & 0.138 & & - & & -1.131 & 0.442 & 0.415 \\
\hline F-statistic & 6.658 & 0.000 & 0.000 & 5.560 & 0.001 & 0.001 & 8.086 & 0.000 & 0.000 & 6.522 & 0.000 & 0.000 \\
\hline F-White (Heteroscedasticity) & 3.869 & 0.002 & 0.002 & 3.058 & 0.008 & 0.008 & 3.373 & 0.006 & 0.006 & 2.771 & 0.014 & 0.014 \\
\hline Adjusted R-squared & 0.350 & & - & 0.352 & - & & 0.403 & $\begin{array}{l}- \\
-\end{array}$ & & 0.397 & & - \\
\hline \multicolumn{13}{|l|}{ Electric machinery (47 countries) } \\
\hline Constant (thousands) & -27.127 & 0.177 & 0.059 & -23.220 & 0.269 & 0.074 & -27.181 & 0.162 & 0.030 & -28.477 & 0.151 & 0.022 \\
\hline GDPHy2-GDPHy1 & 0.298 & 0.487 & 0.462 & 0.266 & 0.541 & 0.511 & -0.708 & 0.154 & 0.167 & -0.697 & 0.165 & 0.182 \\
\hline JXHy1 & 0.024 & 0.865 & 0.937 & 0.043 & 0.766 & 0.889 & 0.401 & 0.000 & 0.048 & 0.400 & 0.000 & 0.051 \\
\hline gPXJPH & -1363.213 & 0.124 & 0.056 & -1281.443 & 0.154 & 0.068 & -994.007 & 0.248 & 0.201 & -1015.136 & 0.243 & 0.197 \\
\hline AERHy1 or AERHy2-AERHy1 & 5.011 & 0.000 & 0.029 & 5.148 & 0.000 & 0.027 & 3.659 & 0.000 & 0.001 & 3.323 & 0.004 & 0.016 \\
\hline UEHy1 or UEHy2-UEHy1 & - & & - & -0.673 & 0.506 & 0.544 & - & - & - & 0.605 & 0.634 & 0.541 \\
\hline F-statistic & 10.479 & 0.000 & 0.000 & 8.362 & 0.000 & 0.000 & 11.975 & 0.000 & 0.000 & 9.446 & 0.000 & 0.000 \\
\hline F-White (Heterosced & 17.337 & 0.000 & 0.000 & 13.080 & 0.000 & 0.000 & 7.458 & 0.000 & 0.000 & 6.114 & 0.000 & 0.000 \\
\hline Adjusted R-squared & 0.457 & - & - & 0.450 & - & - & 0.494 & - & - & 0.484 & - & - \\
\hline \multicolumn{13}{|c|}{ Transportation machinery (41 countries) } \\
\hline Constant (thousands) & 5.212 & 0.796 & 0.625 & 3.855 & 0.836 & 0.743 & 12.404 & 0.512 & 0.134 & 5.781 & 0.771 & 0.585 \\
\hline GDPHy2-GDPHy1 & 0.097 & 0.784 & 0.279 & 0.017 & 0.960 & 0.904 & -0.441 & 0.337 & 0.112 & -0.369 & 0.426 & 0.202 \\
\hline JXHy1 & -0.132 & 0.297 & 0.540 & 0.050 & 0.714 & 0.854 & -0.145 & 0.222 & 0.437 & -0.044 & 0.772 & 0.873 \\
\hline gPXJPH & -926.385 & 0.235 & 0.102 & -606.791 & 0.404 & 0.276 & -677.092 & 0.370 & 0.172 & -697.196 & 0.355 & 0.171 \\
\hline AERHy1 or AERHy2-AERHy1 & 2.310 & 0.305 & 0.387 & 3.201 & 0.133 & 0.172 & 4.312 & 0.051 & 0.034 & 3.683 & 0.105 & 0.127 \\
\hline UEHy1 or UEHy2-UEHy1 & & & & -1.491 & 0.012 & 0.070 & & - & & 2.265 & 0.298 & 0.517 \\
\hline F-statistic & 0.888 & 0.481 & 0.481 & 2.229 & 0.074 & 0.074 & 1.688 & 0.175 & 0.175 & 1.579 & 0.192 & 0.192 \\
\hline F-White (Heteroscedas & 1.761 & 0.124 & 0.124 & 1.720 & 0.124 & 0.124 & 1.525 & 0.189 & 0.189 & 1.492 & 0.192 & 0.192 \\
\hline Adjusted R-squared & -0.012 & 1 & - & 0.136 & - & & 0.066 & - & & 0.069 & & - \\
\hline
\end{tabular}

Notes: Industries and terminology are as defined in the notes to Appendix Table A1. 